NASA/TM-1999-209078

\title{
A Three-Dimensional Coupled Internal/External Simulation of a Film-Cooled Turbine Vane
}

James D. Heidmann

Glenn Research Center, Cleveland, Ohio

David L. Rigby

Dynacs Engineering Co., Inc., Brook Park, Ohio

Ali A. Ameri

AYT Corporation, Cleveland, Ohio 
Since its founding, NASA has been dedicated to the advancement of aeronautics and space science. The NASA Scientific and Technical Information (STI) Program Office plays a key part in helping NASA maintain this important role.

The NASA STI Program Office is operated by Langley Research Center, the Lead Center for NASA's scientific and technical information. The NASA STI Program Office provides access to the NASA STI Database, the largest collection of aeronautical and space science STI in the world. The Program Office is also NASA's institutional mechanism for disseminating the results of its research and development activities. These results are published by NASA in the NASA STI Report Series, which includes the following report types:

- TECHNICAL PUBLICATION. Reports of completed research or a major significant phase of research that present the results of NASA programs and include extensive data or theoretical analysis. Includes compilations of significant scientific and technical data and information deemed to be of continuing reference value. NASA's counterpart of peerreviewed formal professional papers but has less stringent limitations on manuscript length and extent of graphic presentations.

- TECHNICAL MEMORANDUM. Scientific and technical findings that are preliminary or of specialized interest, e.g., quick release reports, working papers, and bibliographies that contain minimal annotation. Does not contain extensive analysis.

- CONTRACTOR REPORT. Scientific and technical findings by NASA-sponsored contractors and grantees.
- CONFERENCE PUBLICATION. Collected papers from scientific and technical conferences, symposia, seminars, or other meetings sponsored or cosponsored by NASA.

- SPECIAL PUBLICATION. Scientific, technical, or historical information from NASA programs, projects, and missions, often concerned with subjects having substantial public interest.

- TECHNICAL TRANSLATION. Englishlanguage translations of foreign scientific and technical material pertinent to NASA's mission.

Specialized services that complement the STI Program Office's diverse offerings include creating custom thesauri, building customized data bases, organizing and publishing research results ... even providing videos.

For more information about the NASA STI Program Office, see the following:

- Access the NASA STI Program Home Page at http://www.sti.nasa.gov

- E-mail your question via the Internet to help@sti.nasa.gov

- Fax your question to the NASA Access Help Desk at (301) 621-0134

- Telephone the NASA Access Help Desk at (301) 621-0390

- Write to:

NASA Access Help Desk

NASA Center for AeroSpace Information 7121 Standard Drive

Hanover, MD 21076 
NASA/TM-1999-209078

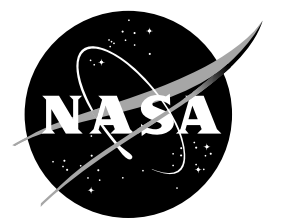

\section{A Three-Dimensional Coupled Internal/External Simulation of a Film-Cooled Turbine Vane}

James D. Heidmann

Glenn Research Center, Cleveland, Ohio

David L. Rigby

Dynacs Engineering Co., Inc., Brook Park, Ohio

Ali A. Ameri

AYT Corporation, Cleveland, Ohio

Prepared for the

44th Gas Turbine and Aeroengine Congress, Exposition, and Users' Symposium sponsored by the International Gas Turbine Institute of the American Society of Mechanical Engineers

Indianapolis, Indiana, June 7-10, 1999

National Aeronautics and Space Administration

Glenn Research Center 
Available from

NASA Center for Aerospace Information 7121 Standard Drive

Hanover, MD 21076

Price Code: A03
National Technical Information Service 5285 Port Royal Road Springfield, VA 22100 Price Code: A03 


\title{
A THREE-DIMENSIONAL COUPLED INTERNAL/EXTERNAL SIMULATION OF A FILM-COOLED TURBINE VANE
}

\author{
James D. Heidmann \\ NASA Glenn Research Center \\ Cleveland, $\mathrm{OH} 44135$ \\ David L. Rigby \\ Dynacs Engineering Co., Inc. \\ Brook Park, OH 44142 \\ Ali A. Ameri \\ AYT Corporation \\ NASA Glenn Research Group \\ Cleveland, $\mathrm{OH} 44135$
}

\begin{abstract}
A three-dimensional Navier-Stokes simulation has been performed for a realistic film-cooled turbine vane using the LeRC-HT code. The simulation includes the flow regions inside the coolant plena and film cooling holes in addition to the external flow. The vane is the subject of an upcoming NASA Glenn Research Center experiment and has both circular cross-section and shaped film cooling holes. This complex geometry is modeled using a multiblock grid which accurately discretizes the actual vane geometry including shaped holes. The simulation matches operating conditions for the planned experiment and assumes periodicity in the spanwise direction on the scale of one pitch of the film cooling hole pattern. Two computations were performed for different isothermal wall temperatures, allowing independent determination of heat transfer coefficients and film effectiveness values. The results indicate separate localized regions of high heat flux in the showerhead region due to low film effectiveness and high heat transfer coefficient values, while the shaped holes provide a reduction in heat flux through both parameters. Hole exit data indicate rather simple skewed profiles for the round holes, but complex profiles for the shaped holes with mass fluxes skewed strongly toward their leading edges.
\end{abstract}

\section{NOMENCLATURE}

$\mathrm{A}_{\mathrm{h}} \quad$ hole circular cross-sectional area

c vane true chord

$\mathrm{c}_{\mathrm{p}} \quad$ specific heat

d film hole diameter

h heat transfer coefficient

$\mathrm{m}$ hole mass flow rate

M mass flux ratio $=\left(m / A_{h}\right) /(\rho V)_{\text {in }}$

$\mathrm{p} \quad$ film hole spanwise pitch

q" wall heat flux

s streamwise distance from leading edge

Pr Prandtl number

$\mathrm{Pr}_{\mathrm{t}} \quad$ Turbulent Prandtl number

St Stanton number

$\mathrm{T}$ temperature

V velocity

$\alpha \quad$ streamwise film hole angle

$\Delta \alpha \quad$ streamwise flow deviation $\beta \quad$ spanwise film hole angle

$\Delta \beta \quad$ spanwise flow deviation

$\eta \quad$ film effectiveness

$\rho$ density

\section{Subscripts}

ave row-average quantity

aw adiabatic wall conditions

c plenum supply conditions

in freestream inlet conditions

nc smooth vane, no coolant case

o stagnation conditions

w isothermal wall conditions

\section{INTRODUCTION}

Film cooling is commonly used in advanced turbine designs to produce a buffer layer of relatively cool air between the turbine blade and the hot freestream gas. The great majority of film cooling studies involve use of a flat plate as an idealization of the actual environment of a film-cooled turbine blade. Early research of this type is summarized by Goldstein (1971). These early studies describe the general behavior of film cooling on a flat plate and define the parameters applied to its description - film effectiveness and heat transfer coefficient. Subsequent research on flat plate film cooling has typically focused on a specific aspect of the problem. Gritsch, et al. (1998) and Thole, et al. (1998) have studied flow exiting holes with expanded exits, also known as shaped holes. The results have shown shaped holes to have flow characteristics much different from round holes. A series of papers by Walters and Leylek (1997), McGovern and Leylek (1997), Hyams and Leylek (1997), and Brittingham and Leylek (1997) provided a detailed computational study of progressively more complex film cooling geometries, including hole shape and orientation. Of particular interest to the present study is the conclusion of Hyams and Leylek (1997) that laterally diffused film holes provide the best film coverage of the shaped hole designs studied. Leylek and Zerkle (1994) were among the first to assess the effect of accounting for the presence of a plenum in a computational study. A jetting effect was identified wherein a low momentum region is produced behind the sharp entrance corner of a film hole. 
Ito et al. (1978) explained the balance which exists between static pressure forces and coolant jet momentum and how this determines film cooling performance on a curved surface. Low momentum cooling jets perform better on the suction side, while high momentum jets do better on the pressure side. Mick and Mayle (1988) showed through experiment that leading edge film cooling, also known as showerhead film cooling, reduces heat flux over the entire flat test body for moderate blowing ratios, despite large increases in heat transfer coefficient in the leading edge region. Garg and Gaugler (1995) computationally demonstrated the profound effect of film hole exit velocity and temperature profile variations on blade surface heat transfer. One of the goals of the present study is thus to accurately describe these profiles for use in new models.

Several computational studies have included plenum effects in realistic blade geometries, most notably Garg and Rigby (1998), Bohn et al. (1997), and Choi (1993). Choi (1993) modeled a film-cooled vane using an overlapped grid with a fine mesh near the coolant hole and plenum and a coarse global mesh. Hole exit profiles were not published. Bohn et al. (1997) modeled a showerhead film-cooled turbine vane and included conjugate conduction effects in the blade. However, the film holes were oriented normal to the blade surface unlike the angled holes of an actual turbine blade. Garg and Rigby (1998) were the first to three-dimensionally model a film-cooled turbine blade with angled showerhead holes and plenum and present hole exit profiles of momentum and stagnation temperature. Simulations of this type have typically been limited to a single idealized plenum and have considered only circular cross-section holes due to the inherent geometrical complexity of the problem.

Relatively few experimental studies on realistic film-cooled turbine blades have been published in the open literature. One such study was performed by Hylton et al. (1988) for a turbine vane similar to the one of the present study. Suction surface, pressure surface, and showerhead film cooling holes were present. Surface temperature data was collected downstream of the cooling holes at midspan, and a finite element solution was used to obtain the internal temperature field and associated wall heat fluxes. No data was recorded in the insulated portion of the vane containing the film cooling holes.

The present study seeks to computationally model a realistic film-cooled turbine vane. The simulation accounts for actual threedimensional vane geometry including plena and film holes. Both film effectiveness and heat transfer coefficient are computed on the entire vane surface and will be compared with future experimental results on the same geometry. The observation of computed threedimensional flow phenomena including hole exit profiles is used to interpret the computed performance of this film cooling design and to suggest simplified models for characterizing the film hole exit properties. Inclusion in the design of the various generic types of film cooling - showerhead, suction, pressure, shaped holes - allows extrapolation of the flow phenomena and accompanying interpretations to other film cooling designs.

\section{VANE GEOMETRY AND NUMERICAL GRID}

The turbine vane of this study is based on an Allied-Signal filmcooled engine design. The present computation models an upcoming NASA Glenn Research Center experiment which will be performed in a linear cascade. The geometry of this test vane is based on the engine vane midspan coordinates, and is scaled up by a factor of 2.943 to allow matching of engine exit Mach number (0.876) and exit Reynolds number $\left(2.9 \times 10^{6}\right.$ based on true chord) with atmospheric inlet conditions. The resultant test vane has a true chord of $0.206 \mathrm{~m}$. The computation of this study is a true prediction and is being used to help design the experiment, as well as to provide data as a "numerical test cell", pending experimental verification. Since the test vane is of constant cross section, only one spanwise pitch of the film hole pattern is discretized, with periodicity enforced at each end. This simplification assumes no effect of endwalls, but greatly reduces the number of grid points required to model the vane.

As shown in Figure 1, the vane has two plena which feed 12 rows of film cooling holes as well as trailing-edge ejection slots, all of which is modeled by the grid. Since the experiment will have no trailing edge ejection, this flow is blocked in the computation although future computational studies may incorporate this feature. Table I provides geometrical data for each row of film holes. Figure 2 shows the definitions of $\alpha$ and $\beta$. Streamwise angles are defined as positive away from the geometric leading edge.

\section{TABLE I}

Film Cooling Hole Geometric Parameters

\begin{tabular}{|c|c|c|c|c|c|}
\hline row & $\mathrm{s} / \mathrm{c}$ & type & $\mathrm{p} / \mathrm{d}$ & $\begin{array}{c}\alpha \\
(\operatorname{deg})\end{array}$ & $\begin{array}{c}\beta \\
(\operatorname{deg})\end{array}$ \\
\hline 1 & -0.447 & $\begin{array}{c}\text { shaped, staggered } \\
\text { pressure side }\end{array}$ & 4.06 & 65.5 & 0 \\
\hline 2 & -0.385 & $\begin{array}{c}\text { shaped, staggered } \\
\text { pressure side }\end{array}$ & 4.06 & 62.9 & 0 \\
\hline 3 & -0.182 & $\begin{array}{c}\text { shaped, staggered } \\
\text { pressure side }\end{array}$ & 4.06 & 63.8 & 0 \\
\hline 4 & -0.142 & $\begin{array}{c}\text { shaped, staggered } \\
\text { pressure side }\end{array}$ & 4.06 & 61.4 & 0 \\
\hline 5 & -0.053 & $\begin{array}{c}\text { round, staggered } \\
\text { showerhead }\end{array}$ & 4.06 & 6.2 & 60 \\
\hline 6 & -0.032 & $\begin{array}{c}\text { round, staggered } \\
\text { showerhead }\end{array}$ & 4.06 & 2.7 & 60 \\
\hline 7 & -0.011 & $\begin{array}{c}\text { round, staggered } \\
\text { showerhead }\end{array}$ & 4.06 & 0.9 & 60 \\
\hline 8 & 0.011 & $\begin{array}{l}\text { round, staggered } \\
\text { showerhead }\end{array}$ & 4.06 & 0.9 & 60 \\
\hline 9 & 0.033 & $\begin{array}{l}\text { round, staggered } \\
\text { showerhead }\end{array}$ & 4.06 & 2.9 & 60 \\
\hline 10 & 0.054 & $\begin{array}{l}\text { round, staggered } \\
\text { showerhead }\end{array}$ & 4.06 & 4.4 & 60 \\
\hline 11 & 0.116 & $\begin{array}{l}\text { round, aligned } \\
\text { suction side }\end{array}$ & 2.71 & 44.5 & 0 \\
\hline 12 & 0.157 & $\begin{array}{l}\text { round, aligned } \\
\text { suction side }\end{array}$ & 2.71 & 47.0 & 0 \\
\hline
\end{tabular}

All rows have circular cross-section holes except for rows 1 through 4, which have shaped holes. These holes are expanded in both the lateral and downstream directions in an attempt to achieve 
better film coverage. The expansion angle on each side of the holes and on the downstream edge is $10 \mathrm{deg}$. Rows 5 through 10 consist of compound-angle holes in the showerhead region which have an inclination of $60 \mathrm{deg}$. in the spanwise direction. Rows 11 and 12 have a spanwise pitch equal to two-thirds of the spanwise pitch of rows 1 through 10, so the overall vane spanwise pitch covers 3 holes each in rows 11 and 12, and 2 holes each in rows 1 through 10 . In rows 1 through 10, the holes are in a staggered arrangement, so it was necessary to split some holes on the spanwise periodic boundary.

A multi-block grid approach is adopted to model this complex geometry, in which a system of locally structured grid blocks is generated in a globally unstructured assembly. This multi-block system is generated in the present study by the grid generation program GridPro $^{\mathrm{TM}}$ (Program Development Corporation, 1997). This program produces a body-fitted multi-block grid with hexahedral cells and full face-matching blocks. The present grid was initially composed of 2298 blocks, which were merged to produce a grid consisting of 140 blocks using the Method of Weakest Descent as described in Rigby (1996) and Rigby et al. (1997a). The grid is composed of $1.2 \times 10^{6}$ computational cells. Algebraic clustering produces a $\mathrm{y}^{+}$value of less than 1.0 at the first grid point away from the wall at all locations. Several calculations were performed for varying wall spacings, and it was found that further reductions produced little change in the solution. The grid consists of 20 cells across both the inlet and outlet boundaries, 60 cells on the periodic boundary, over 200 cells around the vane, and 44 cells from the vane to the periodic boundary. These values are consistent with good computational practice. A blade-to-blade view of the computational grid is shown in Figure 3.

Figure 4 shows the grid in the leading edge region of the vane. The faithful discretization of the shaped holes should be noted, as well as the ability of the multi-block grid to transition from a very fine structure near locations of complex geometry such as film holes to a coarser structure far from the holes. In addition, the clustered viscous grids abut all wall boundaries without extending into the flow field. These features would be impossible for a single-block grid on even modestly complex geometries, and serve to greatly reduce the number of grid points necessary to adequately resolve the geometry.

\section{COMPUTATIONAL METHOD}

The simulations in this study were performed using a multiblock computer code called LeRC-HT, previously known as TRAF3D.MB (Steinthorsson et al., 1993) which is based on a single block code designed by Arnone et al. (1991). This code is a general purpose flow solver designed for simulations of flows in complicated geometries. The code solves the full compressible Reynolds-averaged Navier-Stokes equations using a multi-stage Runge-Kutta-based multigrid method. It uses the finite volume method to discretize the equations. The code uses central differencing together with artificial dissipation to discretize the convective terms. The overall accuracy of the code is second order. The present version of the code (Rigby, 1996, Rigby et al., 1997b and Ameri et al. 1997) employs the k- $\omega$ turbulence model developed by Wilcox (1994a, 1994b), with subsequent modifications by Menter (1993) as implemented by Chima (1996). The k- $\omega$ turbulence model is desirable because it does not require specification of distance to the wall. Such a specification is difficult for complex geometries requiring multi-block grids, such as is considered in the present study. Accurate heat transfer predictions are possible with the code because the model integrates to the walls and no wall functions are used. Rather, the computational grid is generated to be sufficiently fine near walls to produce a $\mathrm{y}^{+}$value of less than 1.0 at the first grid point away from the wall. For heat transfer a constant value of 0.9 for turbulent Prandtl number, $\mathrm{Pr}_{t}$, is used. A constant value of $\operatorname{Pr}=0.72$ is used. Laminar viscosity is a function of temperature through a 0.7 power law (Schlichting, 1979) and $c_{p}$ is taken to be a constant.

The freestream inlet flow to the vane is at an angle of 0 deg. to the axial direction, with all temperatures and pressures normalized by the inlet stagnation values of $294 \mathrm{~K}$ and $101 \mathrm{kPa}$, respectively. The inlet turbulence intensity is $8.0 \%$ and the turbulence scale is $15.0 \%$ of vane true chord. These values were based on preliminary experimental turbulence grid designs. Other inflow quantities are set by means of the upstream-running Riemann invariant. The vane downstream exit flow is defined by imposing a constant normalized static pressure of 0.576 , which was empirically determined to yield the design exit Mach number of 0.876. Periodicity was enforced in both the blade-to-blade and spanwise directions based on vane and film hole pitches, respectively.

To maintain a true periodic solution, inflow to the plena was provided by defining a region of each plenum wall as an inlet and introducing uniform flow normal to the wall. These regions lie on either side of the internal wall which separates the two plena as shown in Figure 1. The experiment will have spanwise flow in the plenum, but bleed of the plenum flow into the film holes results in a spanwise-varying mass flow rate and static pressure, which would violate spanwise periodicity. Modeling this spanwise plenum flow was attempted computationally, but was abandoned when numerical instabilities prevented convergence. The inflow stagnation temperature to the plena was 0.5 , the velocity was fixed to the constant value required to provide the design mass flow rate to each plenum, and static pressure was extrapolated from the interior. The inflow patch for each plenum was defined to be sufficiently large to yield very low inlet velocities (Mach number $<0.05$ ), allowing each plenum to approximate an ideal plenum.

All solid walls were given a no-slip boundary condition in addition to a fixed temperature. The isothermal wall boundary condition extended to all wall surfaces, including the film hole surfaces and plenum surfaces, so heat transfer in the plena and film holes occurs and provides a stagnation temperature profile in the jet exiting each hole. Two solutions were generated with wall temperatures $\left(\mathrm{T}_{\mathrm{w}}\right)$ of 0.7 and 0.8 , respectively. The predicted wall heat flux distributions $\left(\mathrm{q}_{\mathrm{w}}{ }\right)$ from these solutions were used to solve simultaneously for adiabatic wall temperature $\left(\mathrm{T}_{\mathrm{aw}}\right)$ and Stanton number based on adiabatic wall temperature $\left(\mathrm{St}_{\mathrm{aw}}\right)$ using equation (1), under the assumption that $\mathrm{T}_{\mathrm{aw}}$ and $\mathrm{St}_{\mathrm{aw}}$ are independent of $\mathrm{T}_{\mathrm{w}}$. Having solved for $\mathrm{T}_{\mathrm{aw}}$, film effectiveness $(\eta)$ was found by equation (2) and Stanton number based on inlet stagnation temperature $\left(\mathrm{St}_{\mathrm{in}}\right)$ was found using equation (3) for the 0.7 wall temperature case: 


$$
\begin{gathered}
S t_{a w}=\frac{q_{w}^{\prime \prime}}{\left(\rho V c_{p \text { in }}\left(T_{a w}-T_{w}\right)\right.} \\
\eta=\frac{T_{i n}-T_{a w}}{T_{\text {in }}-T_{c}} \\
S t_{\text {in }}=\frac{q_{w}^{\prime \prime}}{\left(\rho V c_{p \text { in }}\left(T_{\text {in }}-T_{w}\right)\right.}
\end{gathered}
$$

$T_{\text {in }}$ is the inlet stagnation temperature, $T_{c}$ is the coolant temperature, and $\rho, V$, and $c_{p}$ are the density, velocity, and specific heat of the freestream inlet. $\mathrm{St}_{\mathrm{aw}}$ is a dimensionless heat transfer coefficient and may be thought of as the heat transfer coefficient which would result for a coolant flow at the same temperature as the freestream. $\mathrm{St}_{\mathrm{in}}$ is the dimensionless overall heat transfer coefficient, and is simply proportional to local wall heat flux for the $\mathrm{T}_{\mathrm{w}}=0.7$ case. The wall temperature of 0.7 is considered the baseline case because it most closely matches the temperature of an isothermal cooled turbine vane. Volumetric flow data and wall heat fluxes are given for this case. A third calculation was performed for a smooth vane with no film holes or plenum at a wall temperature of 0.7 . The results of this calculation were used to normalize the film-cooling predictions.

Computations were performed in parallel fashion on the NASA Ames Research Center CRAY J90 cluster using 8 processors. Approximately $80 \mathrm{~J} 90$ hours ( 20 equivalent $\mathrm{C} 90$ hours) were required to reach convergence for each calculation. The computations were considered converged when changes to the heat flux after an additional 300 iterations were no longer noticeable either in contour plots or in graphs of span-averaged data versus surface distance. This typically occurred after density residuals had been reduced by more than three orders of magnitude.

\section{COMPUTATIONAL RESULTS}

In lieu of experimental data, the computational results will initially focus on flow physics and detailed phenomena which experiments have difficulty resolving. These results will then be reduced to averaged quantities more amenable to comparison with future data. Computational results are organized into four types of data: volumetric flow quantities, integrated flow quantities, surface quantities, and span-averaged surface quantities.

Figure 5 shows the stagnation temperature on a fixed-span plane through the centerline of the central suction side film holes. It is immediately evident that the stagnation line intersects this plane between rows 6 and 7 (the second and third showerhead rows from the pressure side) since the high temperature isotherms approach the vane. The freestream impinges at this point, diverting the cooling flow from these rows to opposite sides of the vane. A thinning of the thermal boundary layer is also evident on the pressure side, just upstream of the shaped holes. This will manifest itself as an increase in heat flux at this location. A thermal boundary layer is present inside the plenum and film holes due to the isothermal boundary condition there. The resultant stagnation temperature profile in the film jets is of great interest, as is the velocity profile. Both will be showcased later in this report.

Figure 6 illustrates the differing behavior of the suction side round holes and the pressure side shaped holes. In Figures 6(a) and $6(\mathrm{~b})$, the stagnation temperature is shown on normal planes just downstream of rows 3 and 12, respectively. As expected, the shaped holes exhibit improved spreading of the coolant flow in the spanwise direction. It is also evident that the thermal mixing region is somewhat thicker on the pressure side as expected due to lower freestream velocities. On an uncooled blade, this lowers heat transfer because of smaller temperature gradients and associated heat transfer coefficients. However, on a film-cooled blade, the film effectiveness may suffer on the pressure side due to enhanced coolant diffusion. In fact, the design of this vane reflects this, as the improved performance of the shaped holes is needed on the pressure side to offset a more rapid decay of film effectiveness. Also worth noting is the spanwise skewing of the outer thermal boundary layer on the suction side due to its larger share of spanwise flow from the showerhead holes.

Figure 7 shows projected velocity vectors on planes near a hole in row 12. The planes are defined in Figure 2(a). A pair of counterrotating vortices inside the film hole can be seen in Figure 7(a). These are caused by a jetting effect as described by Leylek and Zerkle (1994). The plenum flow makes a sharp turn around the downstream edge of the hole inlet, causing a jet to form which impinges on the upstream side of the hole. This impingement results in a counterrotating pair of vortices which distribute the mass flux along the sides of the hole. Figure 7(b) shows a different pair of counterrotating vortices outside the film hole which are produced by the viscous action of the exiting film jet on the surrounding fluid. These vortices encourage entrainment of hot freestream gas and separation of the cooling jet from the wall. The jetting action which produces the vortices inside the film holes is illustrated in Figure 8 for a hole in row 2. This behavior is present in some form for all holes, but the shape, angle, length, blowing rate, and location of the hole all have an effect on the flow profiles exiting the hole. An understanding of the jetting effect is required to adequately describe hole exit profiles.

To best define the characteristics of flow exiting each row of holes, it is necessary to present those flow properties which have the most fundamental impact on the external flow and are usable in simplified models. The stagnation temperature is directly related to the external heat transfer and is thus presented. The flow is represented by the momentum magnitude and two flow angles. Streamwise and spanwise flow angle deviation from the hole centerline are chosen to represent the flow direction since film hole exit flow is often assumed to be at the hole geometric angle in the absence of detailed data. While other quantities such as pressure and turbulence values are also important, they are not presented in interests of brevity. Figures 9 through 12 present these profiles. In these figures, the hole exit plane at the blade surface is shown for one hole in each row, rotated to be viewed along the hole axis. While small variations exist from hole to hole in a given row, they are small compared to the row to row differences. The shaped holes are scaled to appear approximately the same size as the round holes.

Figure 9 shows contours of momentum magnitude. These plots are normalized by the vane inlet momentum. For the shaped holes, a sharp maximum in momentum occurs along the upstream edge of the hole, with elevated levels also near the sides and downstream edge of the hole. The center of the shaped holes is a very low 
momentum region. This behavior results from the aforementioned jetting effect. The spanwise and downstream expansion of the shaped holes greatly increase the flow area and correspondingly decrease the momentum in the downstream portion of the holes. The circular holes, on the other hand, have a much more uniform momentum distribution. The maximum value for these holes depends on the external pressure variation as well as the hole orientation. The jetting effect and counterrotating vortices occur as for the shaped holes, but the momentum distribution is more uniform because of the lack of spanwise and downstream expansion. The holes in the stagnation region (rows 5 through 7) have a maximum momentum near their trailing edge, while the suction side showerhead holes (rows 8 through 10) have a maximum momentum skewed toward the downstream direction because of the decreasing external static pressure. The suction side holes (rows 11 and 12) are quite skewed toward the downstream direction, although high momentum remnants can be seen near their leading edge due to the high momentum associated with these holes. The combined effect produces an inverted momentum profile, where the maximum values lie in a ring around the lower momentum region in the center of the hole.

Figure 10 shows the stagnation temperature profiles for each row of holes. These plots are normalized by the plenum inlet and wall temperatures. Temperatures closer to the plenum inlet temperature tend to occur at locations of high momentum because this fluid has been influenced less by the warmer plenum and hole walls. Because of this phenomenon, it should be possible to correlate the stagnation temperature with momentum, much as it is for a fully developed channel flow with heat transfer. It would then only be necessary to model the hole exit momentum to obtain both parameters. The higher temperatures near the center of the shaped holes result from the low momentum, which allows the warmer external flow to approach the hole exit plane as seen also in Figure 5.

Figure 11 presents profiles of streamwise flow angle relative to the hole geometric streamwise angle. Positive values represent deflections away from the vane leading edge. The low momentum regions of the shaped holes show large streamwise deflections in the streamwise direction due to the downstream diffusion of the hole. In fact, the flow in this region is nearly parallel to the vane surface. This observation is corroborated by Figure 8 . The shaped holes also exhibit a thin region of flow nearly aligned with the hole angle at the upstream edge. This coincides with the high momentum region of Figure 9, and indicates that a large fraction of the mass flux in the shaped holes occurs in this region. It may thus be possible to model the flow from these shaped holes as if it were issuing from a thin slot with an inviscid boundary condition immediately downstream representing the low flux region near the hole center.

The behavior of the showerhead holes (rows 5-10) in Figure 11 is easily explainable in terms of the counterrotating vortices associated with the jetting effect. For all these holes, clockwise and counterclockwise vortices exist on the left and right sides of the hole, respectively, as viewed in Figure 11. Thus the flow at the bottom of each hole is away from the centerline, while the opposite is true at the top. As the holes get farther from the stagnation line such as at rows 9 and 10, the flow from the entire hole is deflected downstream, but the vortex effect is still present and is superimposed on the overall deflection angle. Rows 11 and 12 exhibit very little gradient in streamwise deflection angle, and generally have a small deflection toward the leading edge due to the large jetting effect associated with their high momentum.

Figure 12 presents contours of spanwise deflection angle, defined as flow spanwise angle relative to the hole geometric spanwise angle. Here deflection angles in the showerhead injection direction are positive. The shaped holes have a simple behavior, with flow moving away from the centerline due to spanwise diffusion, although row 4 exhibits a skewed profile due to deflection from the showerhead holes. The showerhead holes again are subject to the vortex behavior, with flow tending to move away from the showerhead injection direction along the centerline and toward it on the edges. A similar effect can be inferred in the suction side holes of rows 11 and 12, with a deflection toward the showerhead direction caused by the showerhead flow, especially in row 11.

Table II presents row-average mass flux and stagnation temperature ratios for each row of holes. The mass flux ratios are given in relation to the upstream mass flux. For shaped holes, the mass flux is based on their circular inlet cross-section. It can be seen that the suction side holes have the highest mass flow rate because of their low exit static pressure. Although the mass flux ratio seems high for the suction side holes, their mass flux ratio based on local rather than inlet freestream mass flux is actually about 1.1. The lowest mass flux ratios occur near the stagnation region (rows 5-7) due to the high exit static pressure. The stagnation temperatures are slightly above the plenum inlet temperature of 0.5 due to heat transfer in the plenum and hole pipes. The deviation from 0.5 correlates generally with the amount of plenum wall heat transfer area surrounding each row.

\section{TABLE II}

\section{Film Cooling Hole Row-Average Flow Parameters}

\begin{tabular}{|c|c|c|}
\hline row & $\mathrm{M}=\left(\mathrm{m} / \mathrm{A}_{\mathrm{h}}\right) /(\rho \mathrm{V})_{\text {in }}$ & $\mathrm{T}_{\mathrm{o}, \text { ave }} / \mathrm{T}_{\mathrm{o}, \mathrm{in}}$ \\
\hline 1 & 2.36 & 0.536 \\
\hline 2 & 2.08 & 0.525 \\
\hline 3 & 2.79 & 0.525 \\
\hline 4 & 2.47 & 0.526 \\
\hline 5 & 2.02 & 0.525 \\
\hline 6 & 1.99 & 0.519 \\
\hline 7 & 2.16 & 0.519 \\
\hline 8 & 2.25 & 0.518 \\
\hline 9 & 2.69 & 0.516 \\
\hline 10 & 2.75 & 0.514 \\
\hline 11 & 3.41 & 0.513 \\
\hline 12 & 3.66 & 0.527 \\
\hline
\end{tabular}

Figures 13 through 15 present local wall heat transfer data for the leading edge region of the vane. The spanwise variations are greatest on this portion of the vane. Span-averaged results will be presented for the entire vane. Figure 13 presents the wall heat flux nondimensionalized as overall Stanton number for a wall temperature of 0.7. It should be noted that overall Stanton number may be either positive (heat flux into the vane) or negative (heat flux from vane to 
flow) because the wall temperature is between the freestream and coolant temperatures. The largest heat flux occurs along the stagnation line, between rows 6 and 7, where coolant is not present. Heat flux is also high in streaks between jets on the suction side portion of the showerhead region, and between the holes in the first row of shaped holes on the pressure side. While knowledge of heat flux is important, it is more illuminating to know the relative contributions to heat flux of film effectiveness (adiabatic wall temperature) and heat transfer coefficient. The second solution for wall temperature of 0.8 allows determination of $\mathrm{St}_{\mathrm{aw}}$ and $\mathrm{T}_{\mathrm{aw}}$ through equation 1 by assuming $\mathrm{St}_{\mathrm{aw}}$ to be the same for both solutions at all locations. Film effectiveness is then simply found by equation 2 .

Film effectiveness is the primary determinant of heat flux, and is shown on the vane surface in Figure 14. The stagnation line and the region near row 4 exhibit a low film effectiveness, which simply means the driving temperature for heat transfer is near the freestream temperature. This is consistent with the behavior shown in Figure 13. However, the high heat flux region near rows 9 and 10 in Figure 13 is not accompanied by a low film effectiveness. For an explanation of this behavior, the heat transfer coefficient data must be examined, shown in Figure 15 nondimensionalized as adiabatic wall Stanton number. A pronounced maximum in $\mathrm{St}_{\mathrm{aw}}$ is apparent in the very location of the high heat flux, which explains its existence. Here the driving temperature for heat transfer is not much above the wall temperature, but the intense mixing associated with the showerhead jets interacting with the accelerating freestream causes the heat flux to increase. An interesting phenomenon occurs downstream of the suction side film holes. Although the heat transfer coefficient is high in the regions of high vorticity shown in Figure 7(b), the driving temperature for heat transfer is below the wall temperature as shown in Figure 14, resulting in large negative heat flux (Figure 13). This illustrates the dependence of wall heat flux on wall temperature. Film effectiveness and heat transfer coefficient are independent of wall temperature by this model.

Figures 16 through 18 present the span-averaged film effectiveness, Stanton numbers, and Stanton number ratios, respectively. Span-averages near film holes exclude the hole exit planes. The locations of film hole centerlines are shown by vertical dashed lines. The high Stanton numbers on the pressure side trailing edge result from both low film effectiveness and high heat transfer coefficient. The vane is designed for trailing edge coolant ejection which was not considered in this simulation. This highlights the necessity of using this method of cooling. However, the primary focus of this study is the film cooling performance of the twelve existing film cooling rows.

In Figure 17, a high overall Stanton number at the stagnation line is apparent, but this occurs over a very short streamwise distance, and its effects would likely be mitigated in a conducting metal vane. A region which seems to be of more concern is that between the showerhead holes and the first row of holes on the pressure side. This represents the largest integrated heat flux in the forward portion of the vane. It results from the fact that most of the showerhead coolant goes to the suction side. The adiabatic wall Stanton number is not tremendously high in this region, but the film effectiveness is quite low, indicating a lack of coolant coverage, as shown in Figures 14 and 16. This phenomenon is exhibited to a lesser extent just upstream of the last two rows on the pressure side. A region of very high overall Stanton number is predicted on the aft portion of the suction side. Unlike the pressure side, this behavior would not be affected by inclusion of trailing edge coolant ejection in this constant wall temperature prediction. However, in a conducting vane, the high velocity internal coolant flow associated with trailing edge ejection should keep temperatures low in the thin aft portion of the vane.

As noted previously, the suction side film holes provide a region of large negative heat flux. The film effectiveness actually peaks some distance downstream of the last row of holes, indicating a small jet separation and reattachment. This is unlike the pressure side rows, where a sharp maximum in film effectiveness is reached at the hole exit followed by a rapid decrease. This rapid decrease accounts for the small region of positive heat flux between the two sets of pressure side holes, but the effect is mitigated by the very low heat transfer coefficient provided by the shaped holes.

Figure 18 shows both the overall and adiabatic wall Stanton numbers normalized by the Stanton number for the smooth vane calculation with no coolant. The adiabatic wall Stanton number is greater than 1.0 at nearly all locations, indicating that the presence of film cooling increases heat transfer coefficient over the entire vane. The ratio dips below 1.0 downstream of the last pressure side row due to the low velocity flow exiting the diffusing holes. The overall Stanton number ratio is less than 1.0 at nearly all locations, indicating that the film-cooled vane heat flux is everywhere less than for the uncooled vane, as expected. The only small exception occurs right at the stagnation point, where the ratio barely exceeds 1.0 due to the very low film effectiveness and enhanced heat transfer coefficient in this region.

\section{SUMMARY AND CONCLUSIONS}

A computational study has been performed on a realistic filmcooled turbine vane in anticipation of an upcoming experimental study of the same geometry. Much detailed information has been extracted from the simulations. The two solutions at different isothermal wall temperatures have allowed independent determination of film effectiveness and heat transfer coefficient on the vane surface. Film effectiveness values are shown to be the primary determinant of wall heat flux for a particular wall temperature, although variations in heat transfer coefficient also play a role. Low film effectiveness values are predicted along the stagnation line and just upstream of the first row of pressure side holes due to the absence of coolant flow and flow mixing, respectively. High heat transfer coefficient values on the downstream portions of the showerhead region augment heat flux values and are due to the intense mixing associated with the interaction of accelerating freestream flow and showerhead injection. High heat transfer coefficients near the suction side holes are again due to the intense mixing in this region, but here cooling is enhanced for the baseline wall temperature because of the high film effectiveness. Comparison with a smooth vane, no coolant case indicates that the presence of film cooling almost universally lowers heat flux despite increasing heat transfer coefficient over virtually the entire vane.

Detailed information from the film hole flows is shown in the form of hole exit profiles. All holes exhibit the expected jetting behavior reported by Leylek and Zerkle (1994). The peak mass flux is influenced by both external static pressure variations and the hole orientation. For the circular cross section holes, this peak tends to be skewed both toward the downstream direction as well as toward the injection angle of the hole. The suction side holes exhibit the greatest skewing because these two effects are in the same direction. The shaped holes exhibit a complex behavior with an intense local maximum in mass flux near the leading edge of the hole. The center of the hole contributes very little mass flux, while the sides and 
trailing edge supply coolant that has followed the hole wall around from the leading edge. The shaped holes are effective in producing a low velocity, uniform film layer. All holes exhibit a relatively flat stagnation temperature profile except for the centers of the shaped holes, where the negligible mass flux allows greater influence of the hotter freestream.

The round holes have exit profiles of momentum and stagnation temperature that could be generalized, allowing external vane computations to model their flow. The complex flow in the shaped holes makes it difficult to generalize their exit properties for input to an external vane calculation, but the more spanwise-uniform flow they produce, especially in a staggered arrangement, could be modeled by a two-dimensional wall function or modified slot flow with downstream inviscid wall condition.

\section{REFERENCES}

Ameri, A. A., Steinthorsson, E., and Rigby, D. L., 1997, "Effect of Squealer Tip on Rotor Heat Transfer and Efficiency", ASME Paper 97-GT-128.

Arnone, A., Liou, M.-S., and Povinelli, L. A., 1991, "Multigrid Calculation of Three-Dimensional Viscous Cascade Flows", AIAA Paper 91-3238.

Bohn, D. E., Becker, V. J., and Rungen, A. U., 1997, "Experimental and Numerical Conjugate Flow and Heat Transfer Investigation of a Shower-Head Cooled Turbine Guide Vane", ASME Paper 97-GT-15.

Brittingham, R. A. and Leylek, 1997, "A Detailed Analysis of Film Cooling Physics Part IV: Compound-Angle Injection With Shaped Holes", ASME Paper 97-GT-272.

Chima, R. V., 1996, "A k- $\omega$ Turbulence Model for Quasi-ThreeDimensional Turbomachinery Flows", NASA TM-107051.

Choi, D., 1993, "A Navier-Stokes Analysis of Film Cooling in a Turbine Blade", AIAA Paper 93-0158.

Garg, V. K. and Gaugler, R. E., 1995, "Effect of Velocity and Temperature Distribution at the Hole Exit on Film Cooling of Turbine Blades", ASME Paper 95-GT-2.

Garg, V. K. and Rigby, D. L., 1998, "Heat Transfer on a FilmCooled Blade - Effect of Hole Physics", ASME Paper 98-GT-404.

Gritsch, M., Schulz, A., and Wittig, S., 1998, "Adiabatic Wall Effectiveness Measurements of Film-Cooling Holes With Expanded Exits", ASME Journal of Turbomachinery, Vol. 120, pp. 549-556.

Goldstein, R. J., 1971, Film Cooling, Advances in Heat Transfer, Vol. 7, pp. 321-379.

Hyams, D. G. and Leylek, J. H., 1997, "A Detailed Analysis of Film Cooling Physics Part III: Streamwise Injection with Shaped Holes", ASME Paper 97-GT-271.

Hylton, L. D., Nirmalan, V., Sultanian, V. K., and Kaufman, R. M., 1988, "The Effects of Leading Edge and Downstream Film Cooling on Turbine Vane Heat Transfer", NASA CR-182133.

Ito, S., Goldstein, R. J., and Eckert, E. R. G., 1978, "Film Cooling of a Gas Turbine Blade", ASME Journal of Engineering for Power, Vol. 100, pp. 476-481.

Leylek, J. H. and Zerkle, R. D., 1994, "Discrete-Jet Film Cooling: A Comparison of Computational Results With Experiments", ASME Journal of Turbomachinery, Vol. 116, pp. 358-368.

McGovern, K. T. and Leylek, J. H., 1997, "A Detailed Analysis of Film Cooling Physics Part II: Compound-Angle Injection With Cylindrical Holes", ASME Paper 97-GT-270.

Menter, F. R., 1993, "Zonal Two-Equation k- $\omega$ Turbulence Models for Aerodynamic Flows", AIAA Paper 93-2906.
Mick, W. J. and Mayle, R. E., 1988, "Stagnation Film Cooling and Heat Transfer, Including its Effect within the Hole Pattern", ASME Journal of Turbomachinery, Vol. 110, pp. 66-72.

Program Development Corporation, 1997, "GridPro ${ }^{\mathrm{TM}} / \mathrm{az} 3000$ User's Guide and Reference Manual", White Plains, NY.

Rigby D. L., 1996, "Method of Weakest Descent for Automatic Block Merging", 15th International Conference on Numerical Methods in Fluid Dynamics, Monterey, CA, June 1996.

Rigby D. L., Steinthorsson, E., and Coirier, W. J., 1997a, "Automatic Block Merging Using the Method of Weakest Descent", AIAA Paper 97-0197.

Rigby, D. L., Ameri, A. A., and Steinthorsson, E., 1997b, "Numerical Prediction of Heat Transfer in a Channel with Ribs and Bleed", ASME Paper 97-GT-431.

Schlichting, H., 1979, Boundary Layer Theory, McGraw-Hill, New York, 7th edition, pp. 312-313.

Steinthorsson, E., Liou, M. S., and Povinelli, L. A., 1993, "Development of an Explicit Multiblock/Multigrid Flow Solver for Viscous Flows in Complex Geometries", AIAA-93-2380.

Thole, K., Gritsch, M., Schulz, A., and Wittig, S., 1998, "Flowfield Measurements for Film-Cooling Holes With Expanded Exits", ASME Journal of Turbomachinery, Vol. 120, pp. 327-336.

Walters, D. K. and Leylek, J. H., 1997, "A Detailed Analysis of Film-Cooling Physics Part I: Streamwise Injection With Cylindrical Holes", ASME Paper 97-GT-269.

Wilcox, D. C., 1994a, Turbulence Modeling for CFD, DCW industries, Inc., LaCanada, CA.

Wilcox, D. C., 1994b, "Simulation of Transition With a TwoEquation Turbulence Model", AIAA Journal, Vol. 32, No. 2, pp. $247-$ 255. 


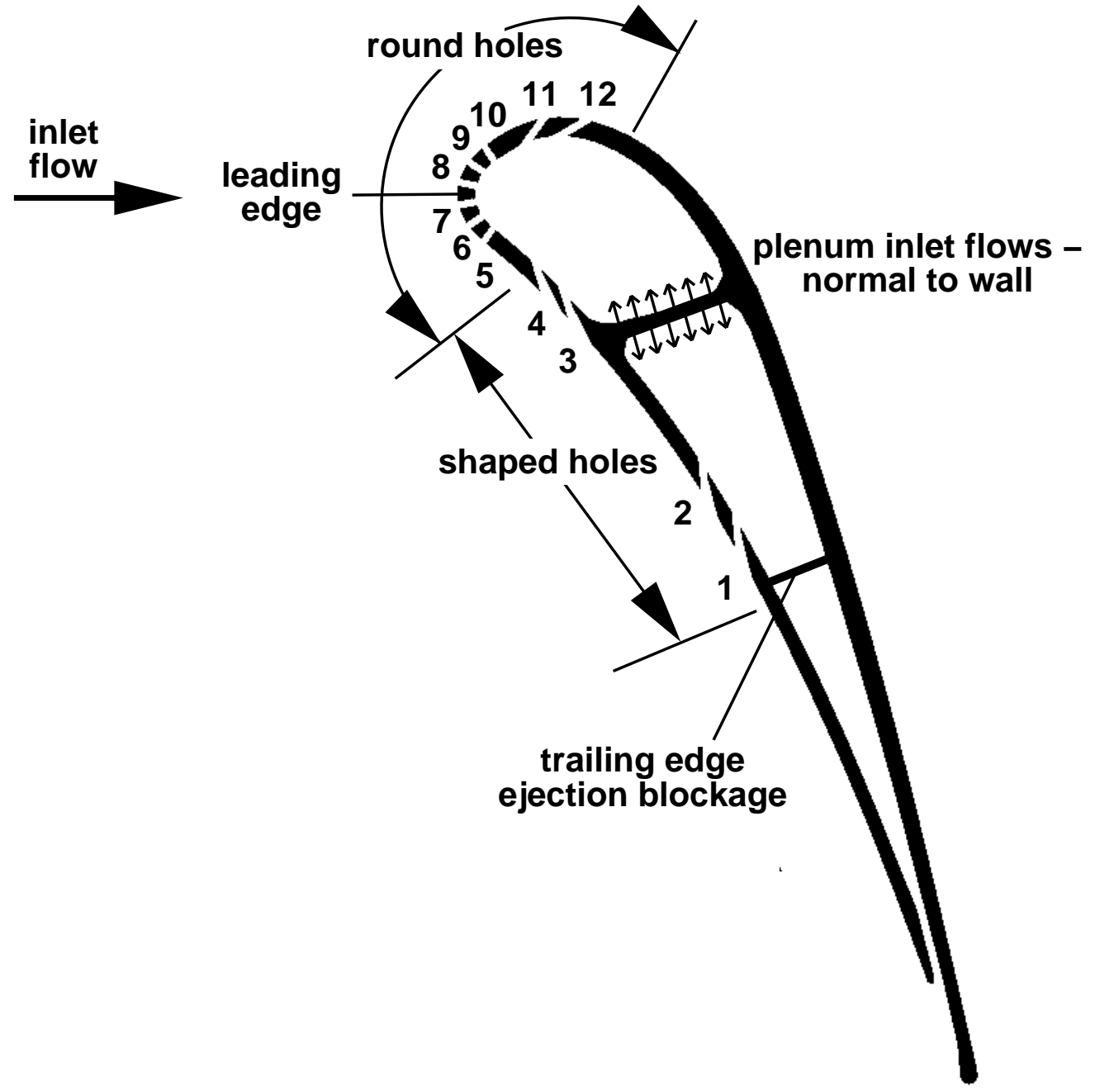

Figure 1: Vane cross-section and film hole row numbers

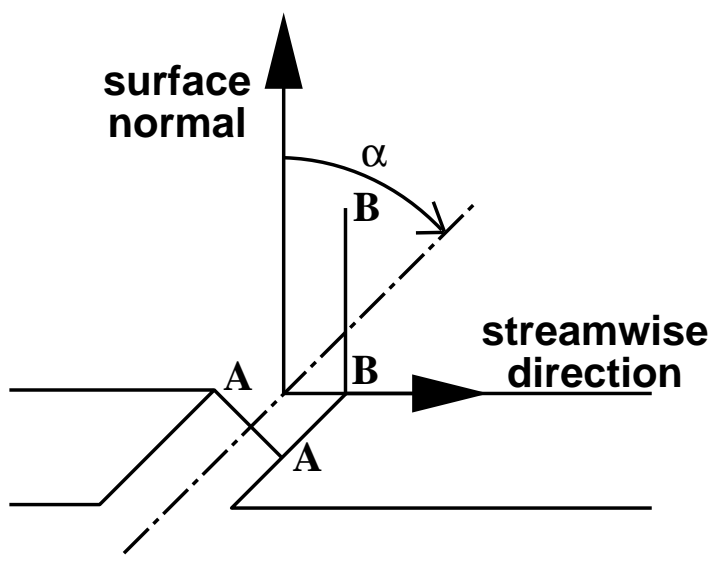

a) streamwise angles

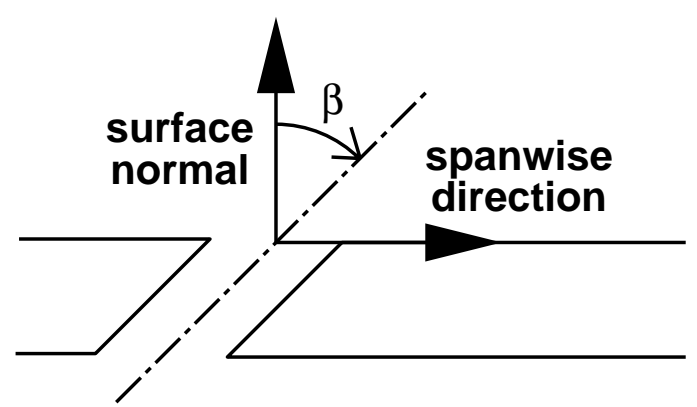

b) spanwise angles

Figure 2: Film hole angles 


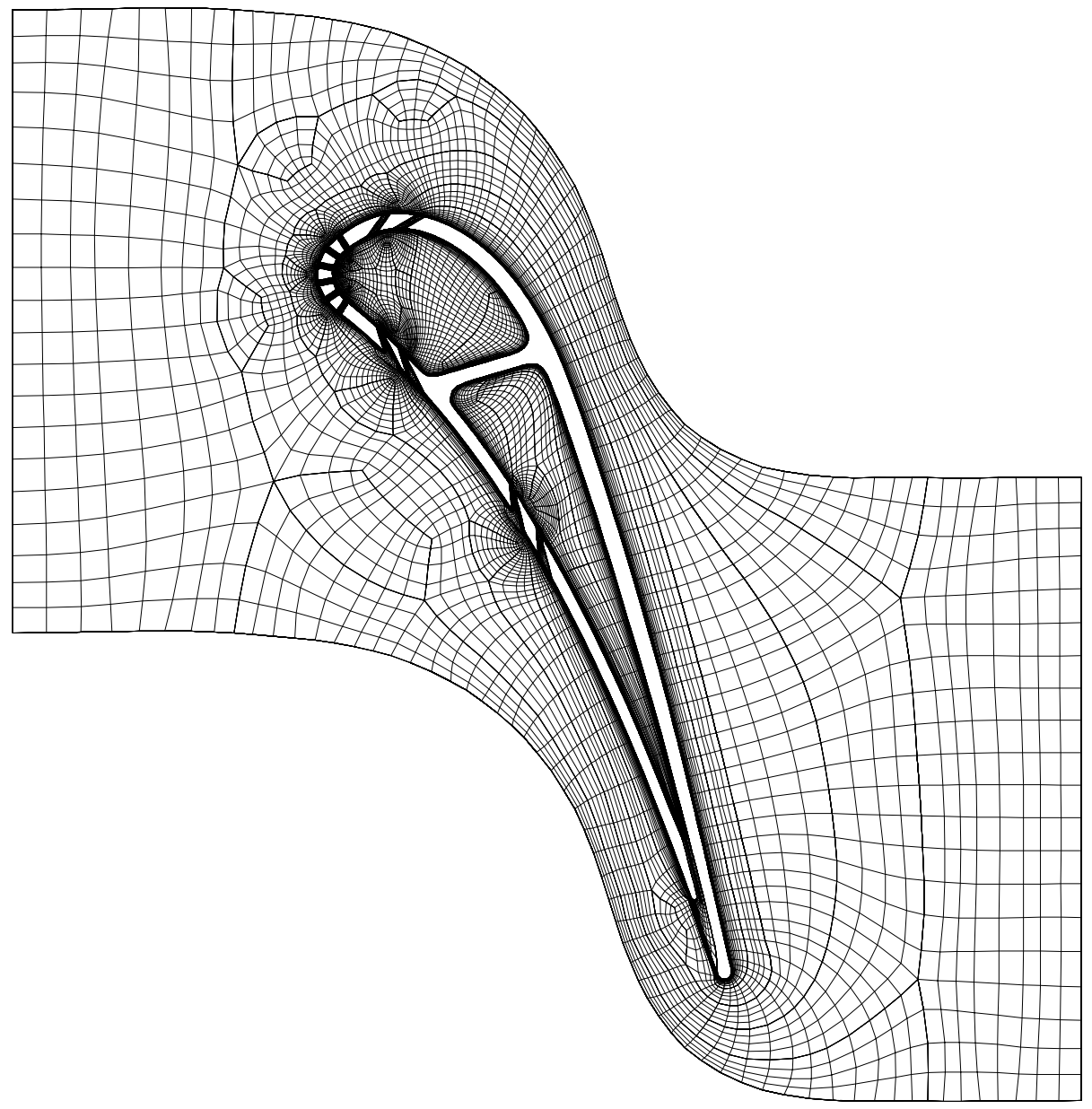

Figure 3: Blade-to-blade view of multiblock computational grid

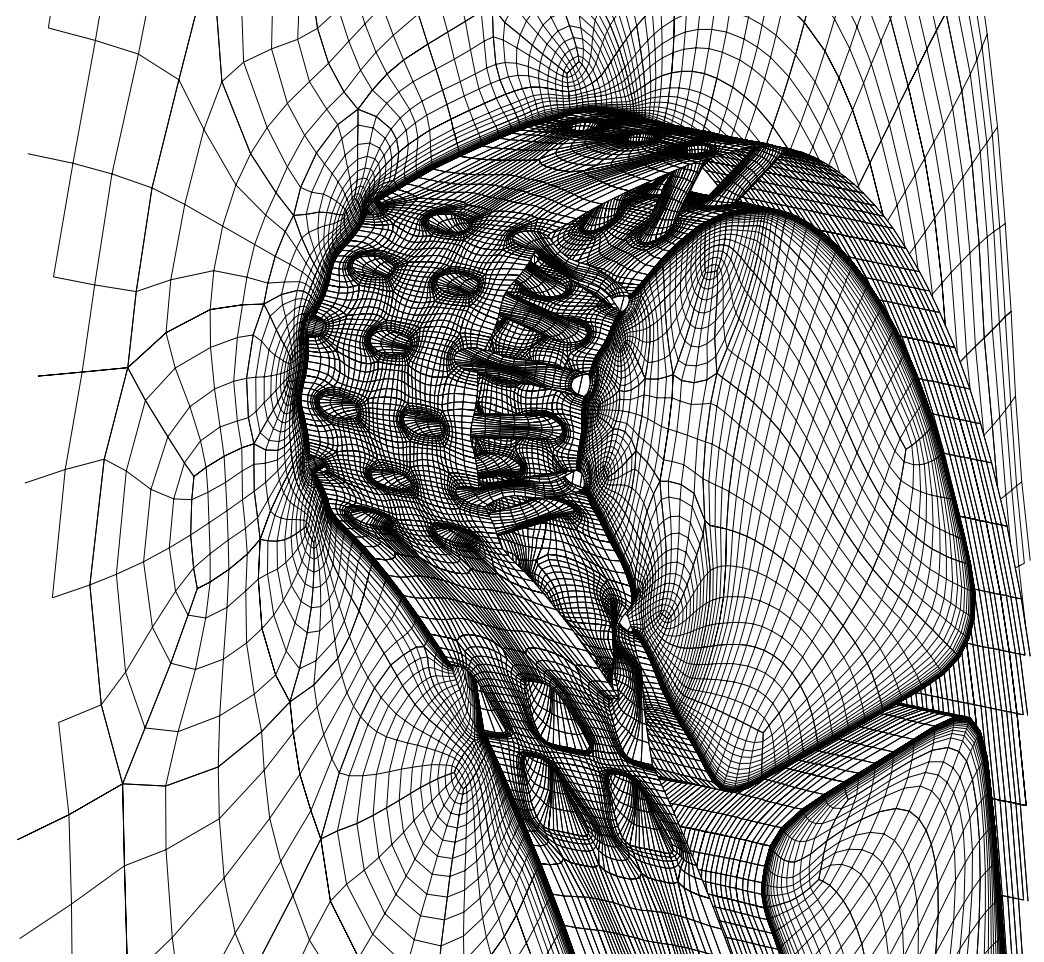

Figure 4: Leading edge region of computational grid 


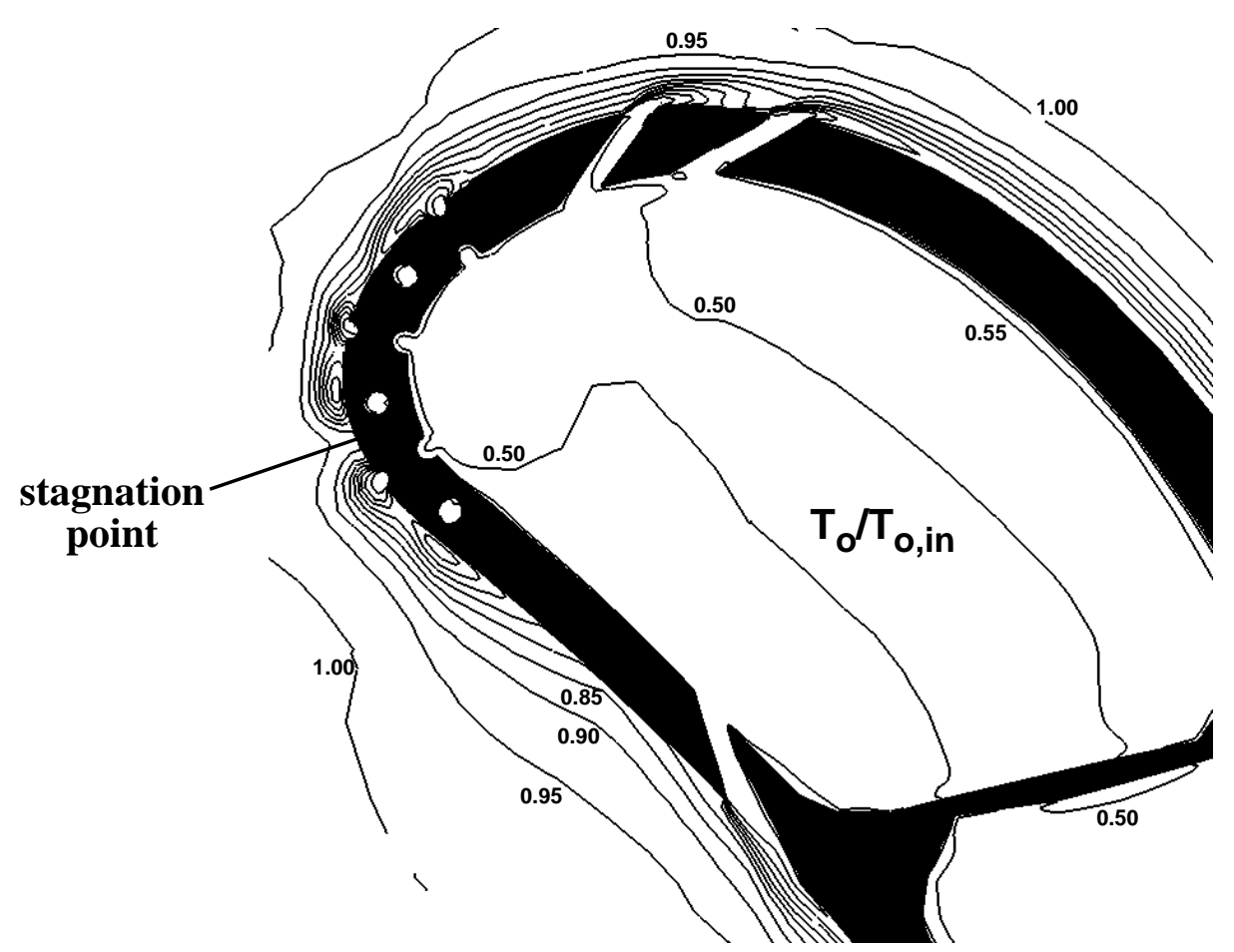

Figure 5: Stagnation temperature contours on plane of fixed span

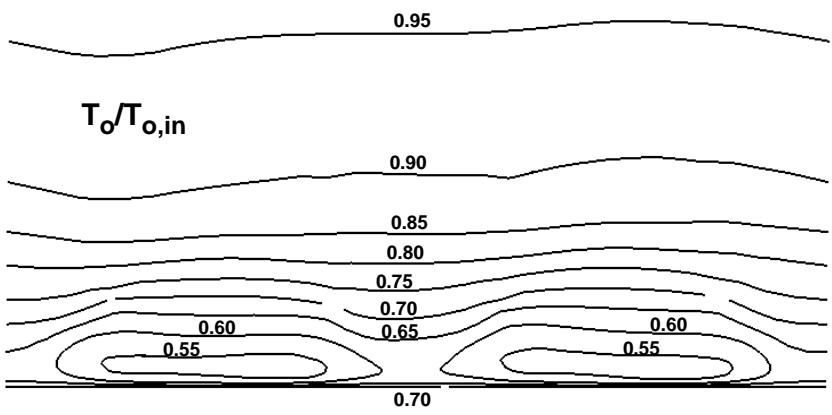

(a) row 3 - pressure side (shaped holes)

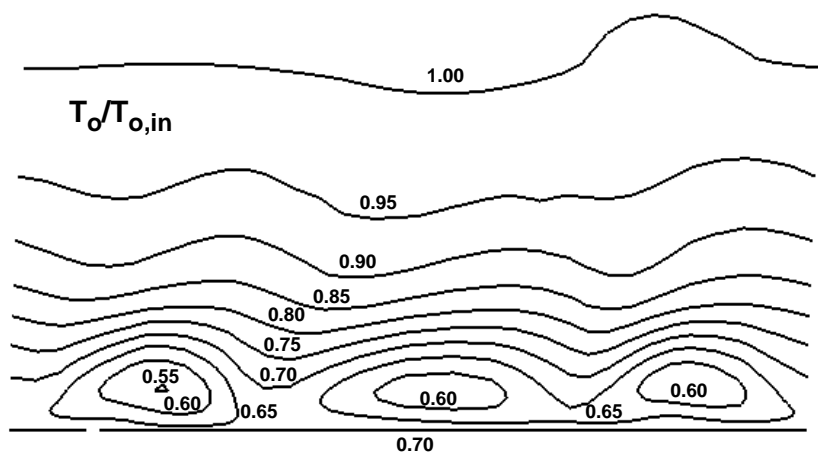

(b) row 12 - suction side (round holes)

Figure 6: Stagnation temperature contours on plane normal to streamwise direction through film hole trailing edges 


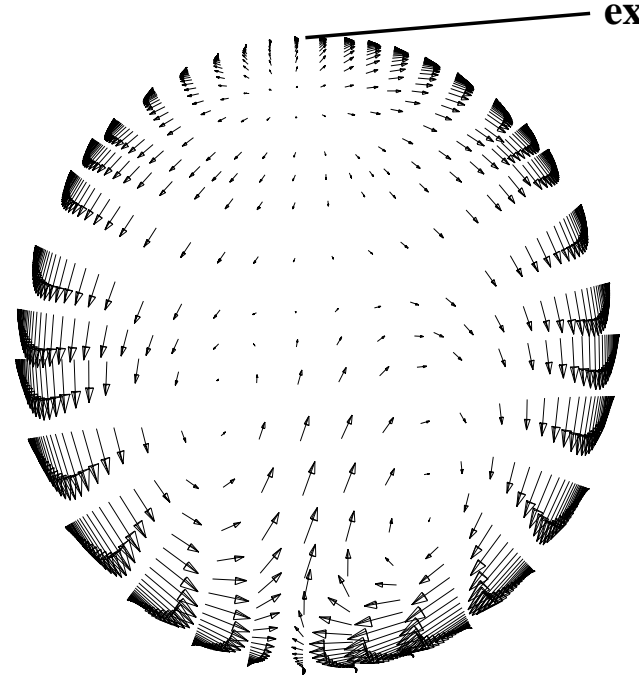

exit plane leading edge

(a) plane $\mathrm{A}-\mathrm{A}$ in Figure 2(a)

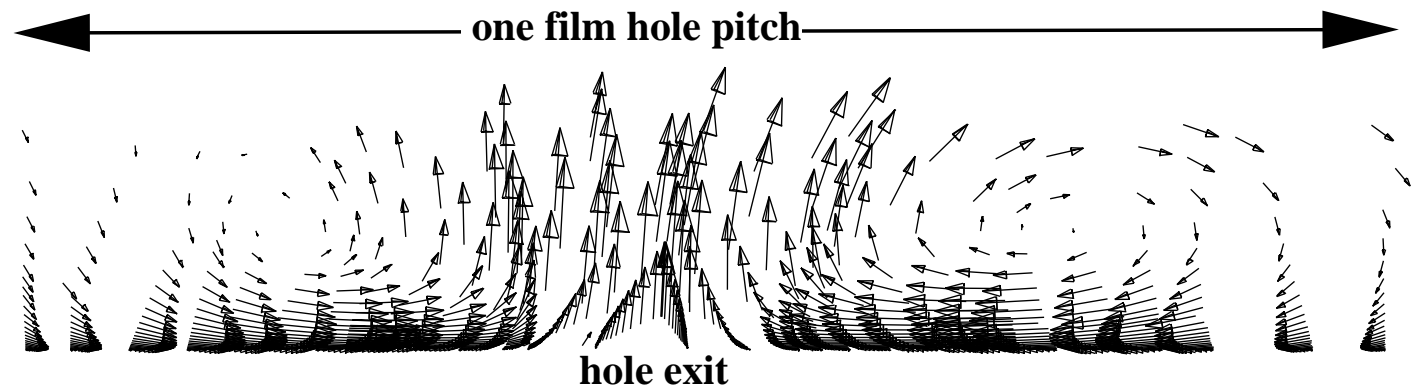

(b) plane B-B in Figure 2(a)

Figure 7: Projected velocity vectors for row 12 - suction side (round holes)

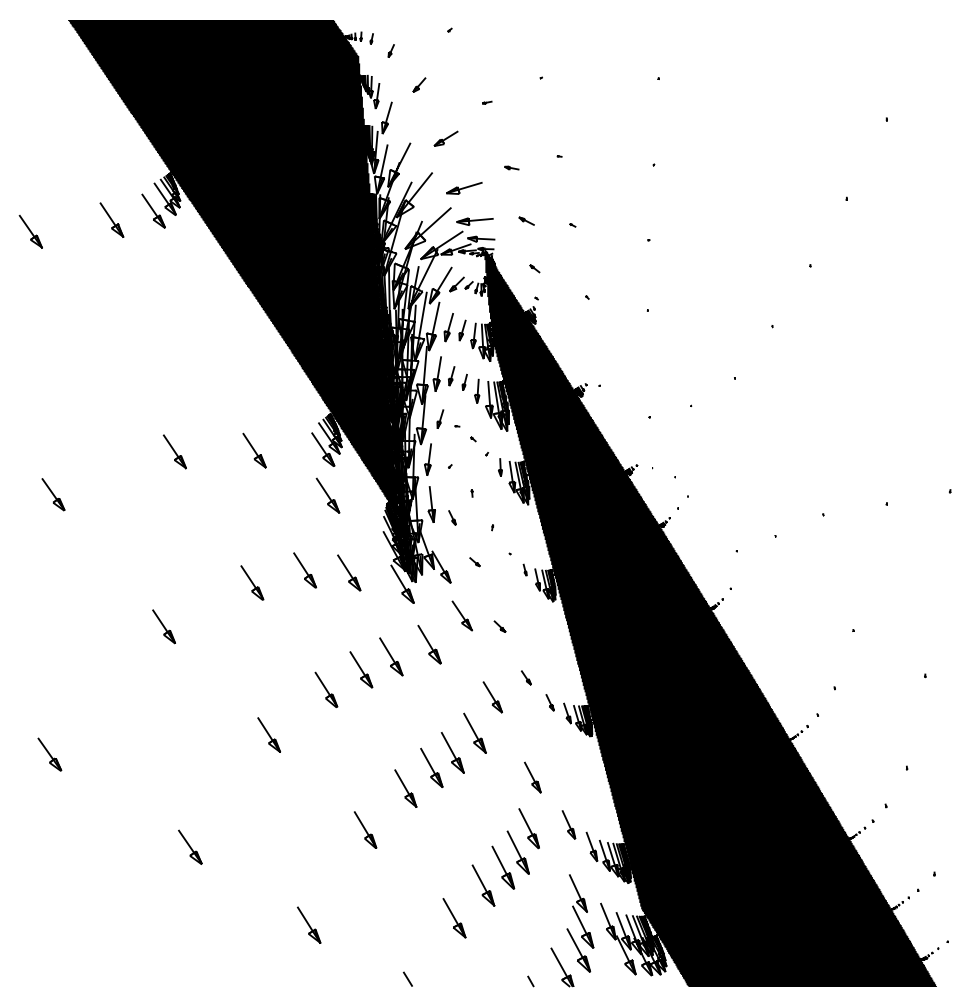

Figure 8: Momentum vectors along hole centerline in row 2 


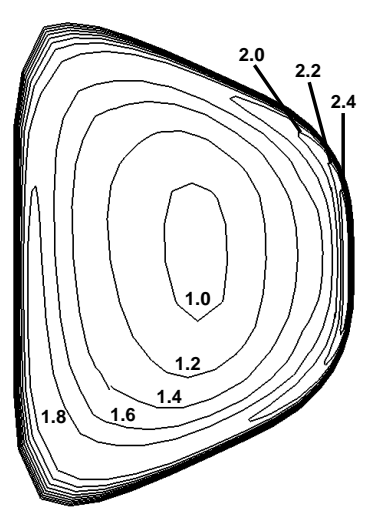

row 1

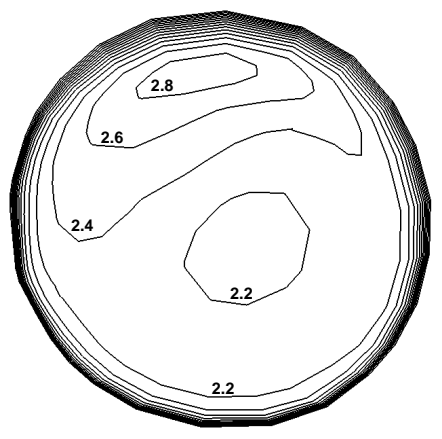

row 5

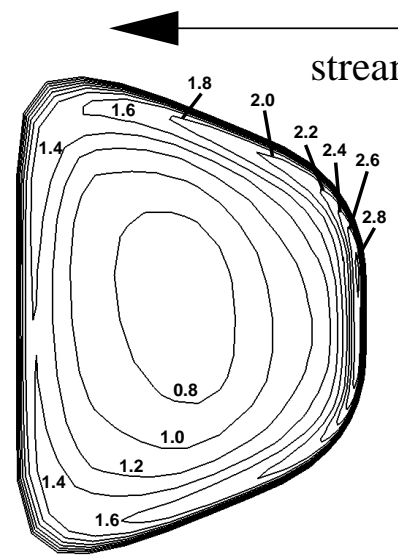

row 2

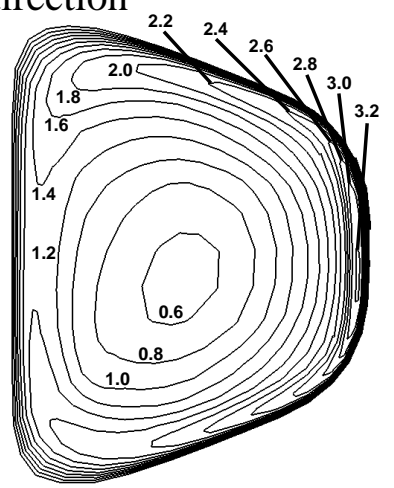

row 3

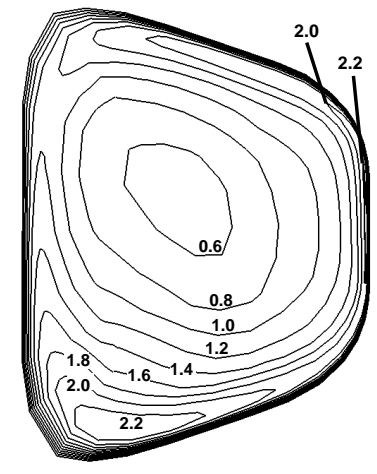

row 4

\section{$\Lambda$}

showerhead injection direction

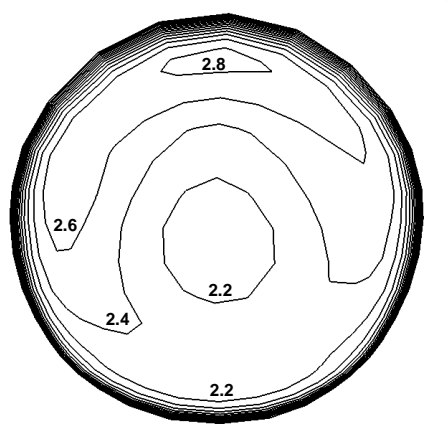

row 6

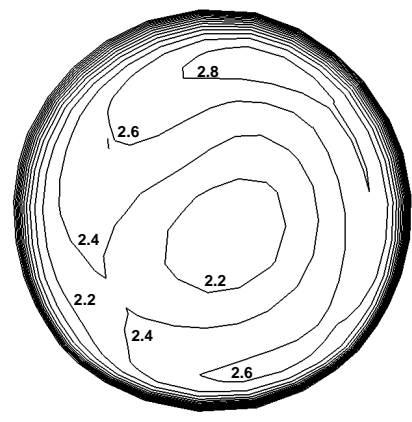

row 7

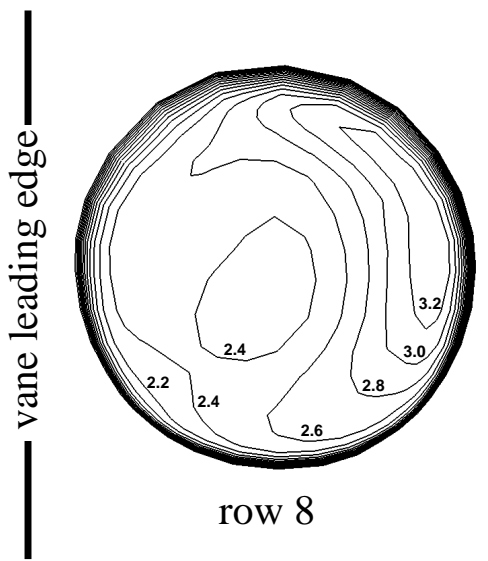

Note: All exit planes viewed along hole centerlines (not to scale)
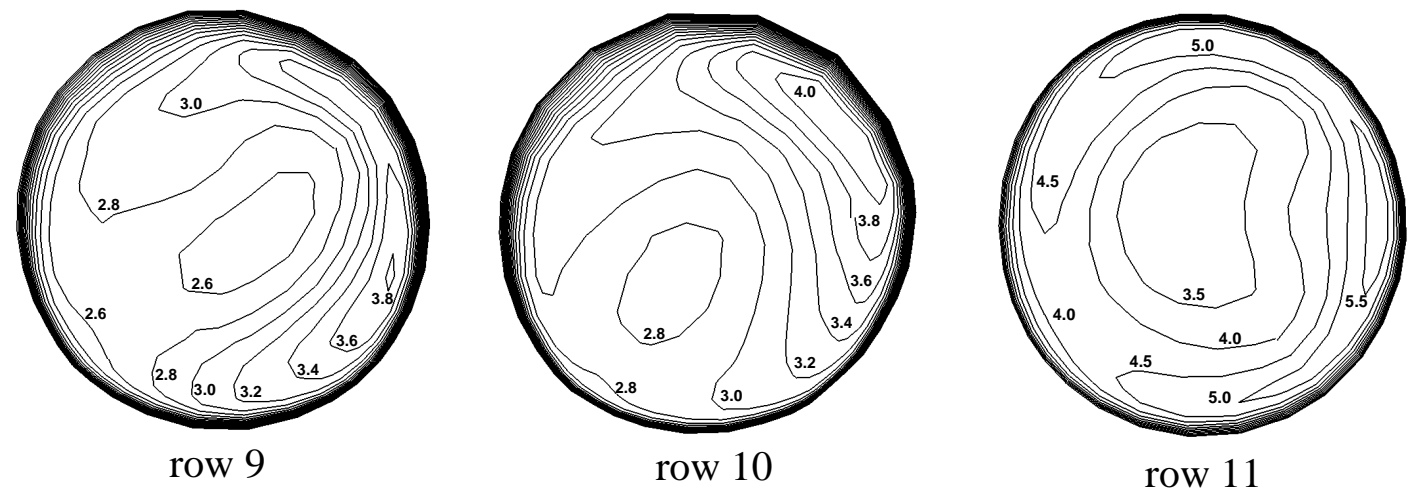

row 11

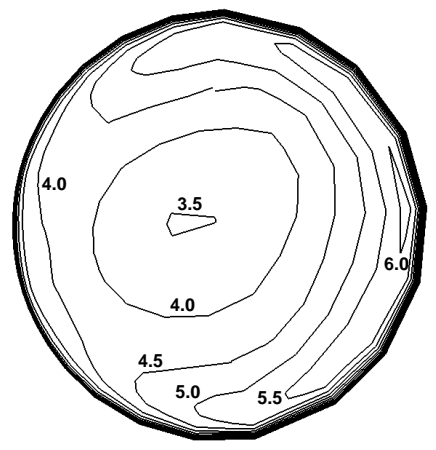

row 12

streamwise direction

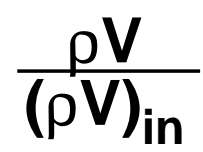

Figure 9: Film hole exit momentum magnitude profiles 


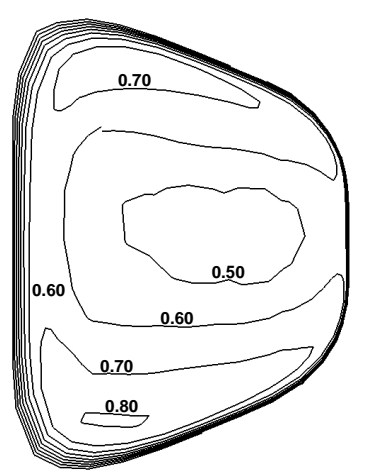

row 1

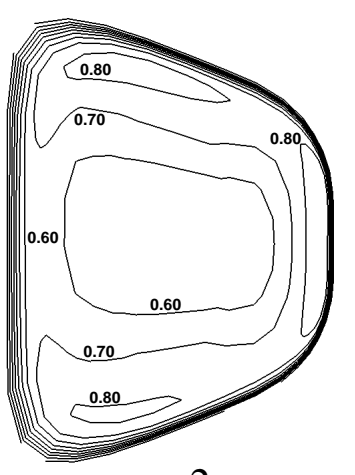

row 2

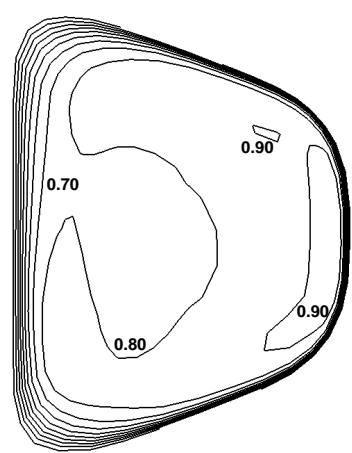

row 3

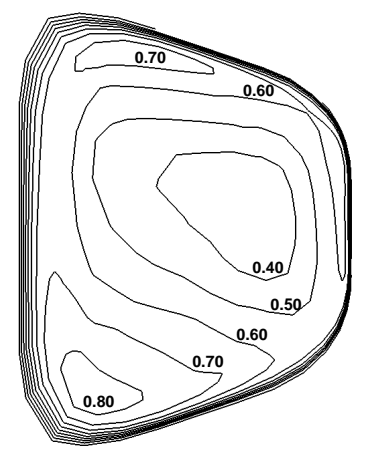

row 4

\section{$\Lambda$}

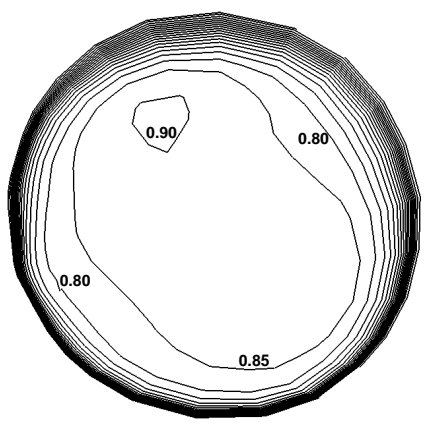

row 5 showerhead injection direction
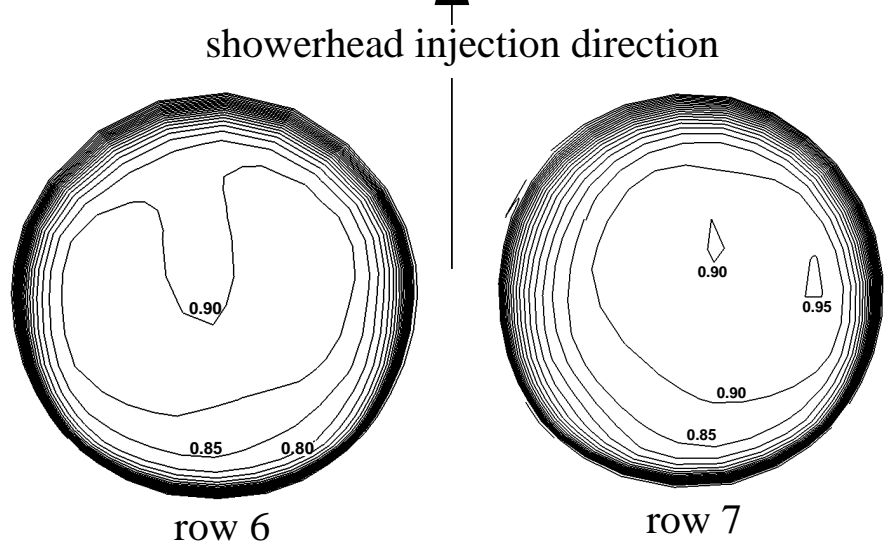

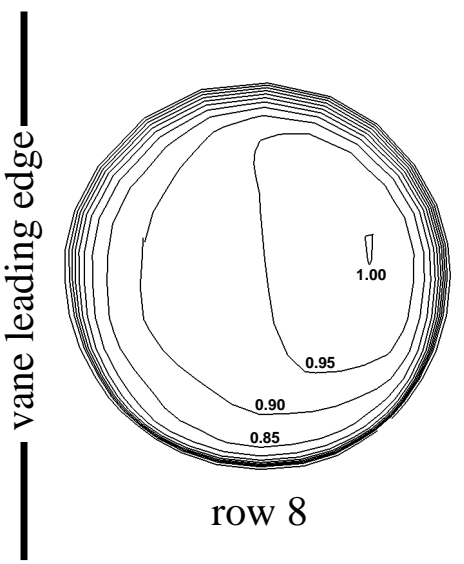

Note: All exit planes viewed along hole centerlines (not to scale)

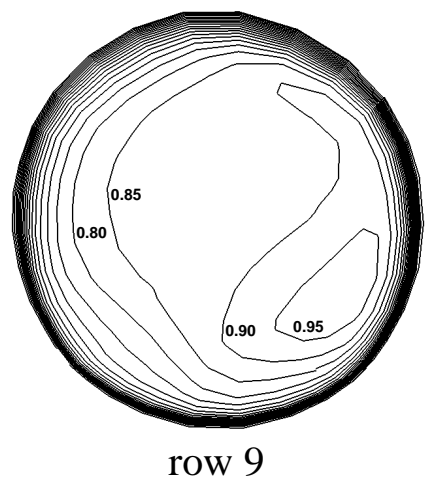

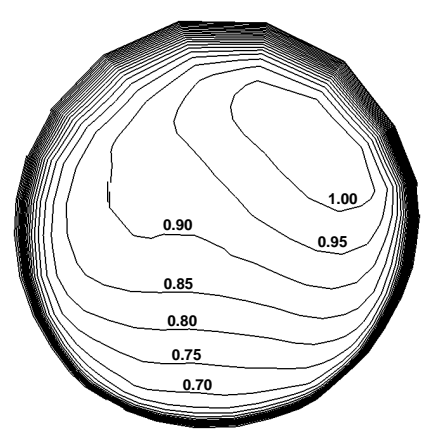

row 10
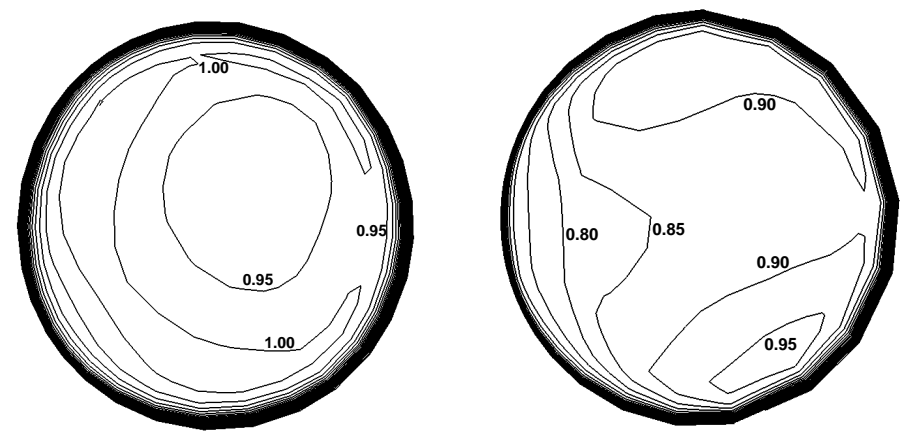

row 11

row 12

streamwise direction

$$
\frac{T_{w}-T_{o}}{T_{w}-T_{c}}
$$

Figure 10: Film hole exit stagnation temperature profiles 


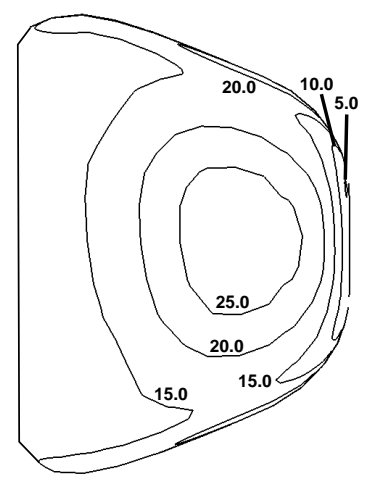

row 1

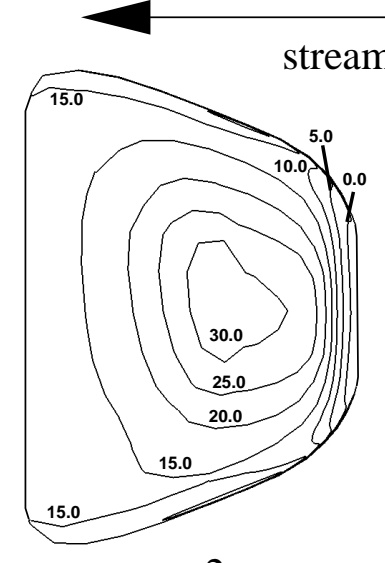

row 2

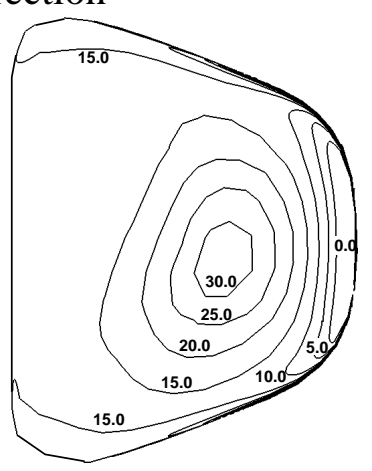

row 3

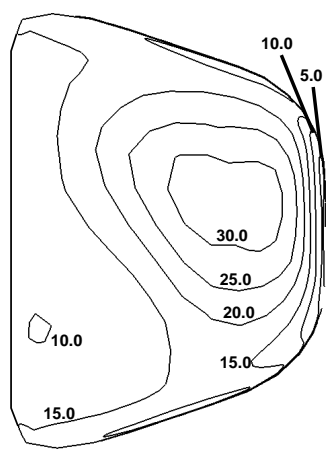

row 4

\section{$\Lambda$}
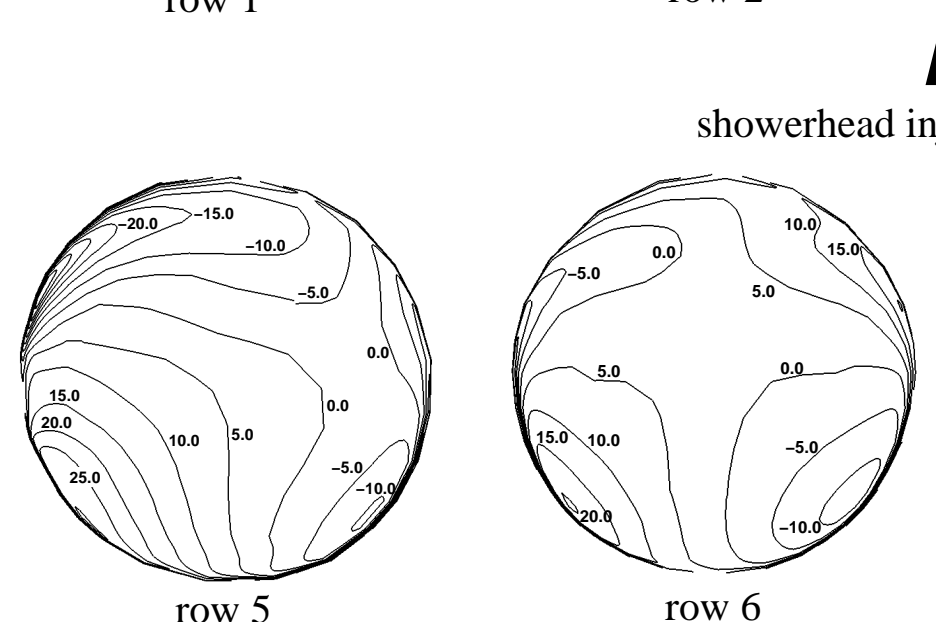

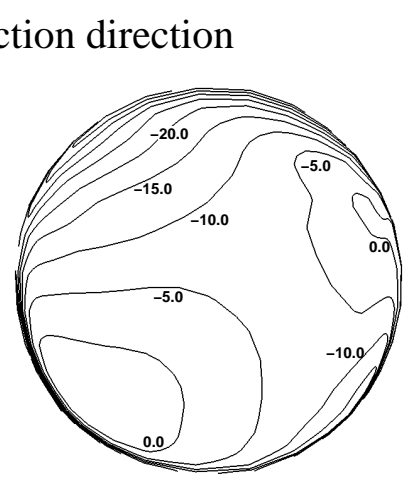

row 7

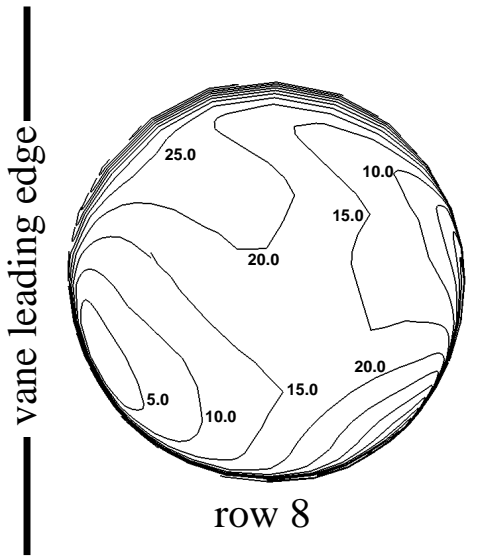

Note: All exit planes viewed along hole centerlines (not to scale)
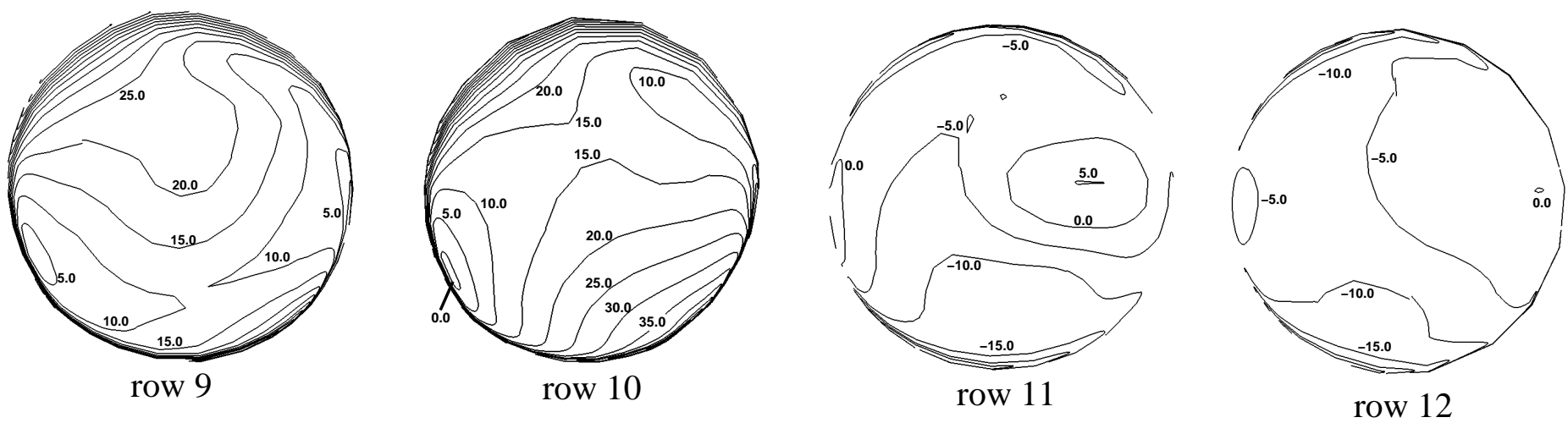

streamwise direction

$\Delta \alpha$ (degrees)

Figure 11: Film hole exit streamwise angle profiles 


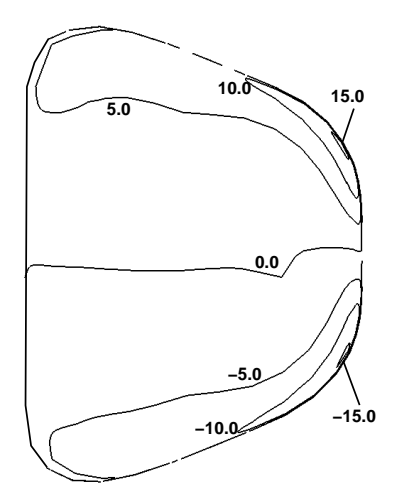

row 1

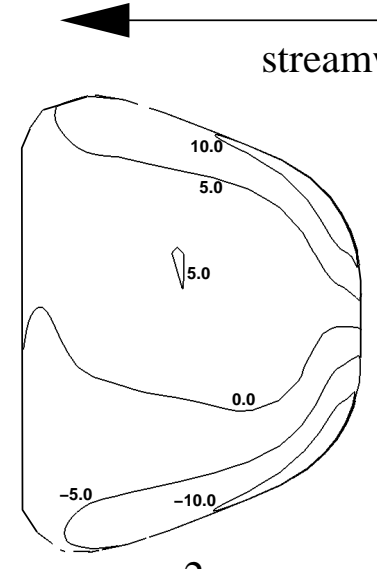

row 2

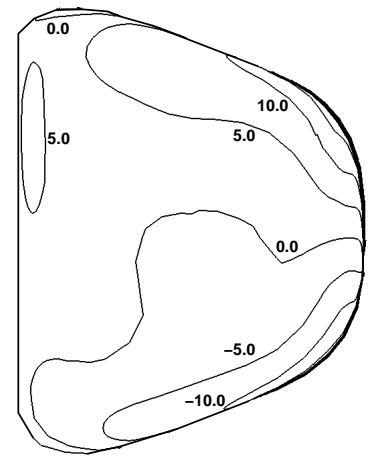

row 3

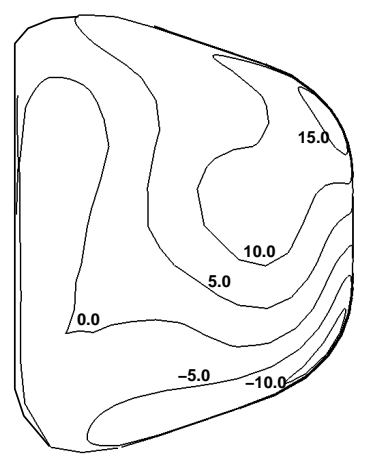

row 4

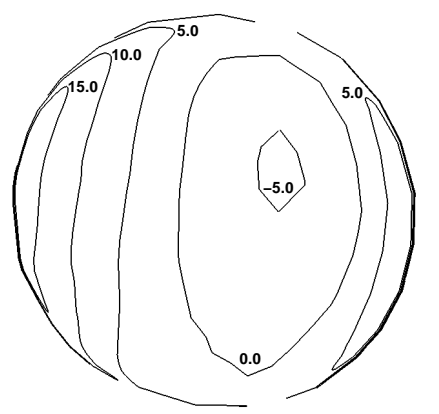

row 5

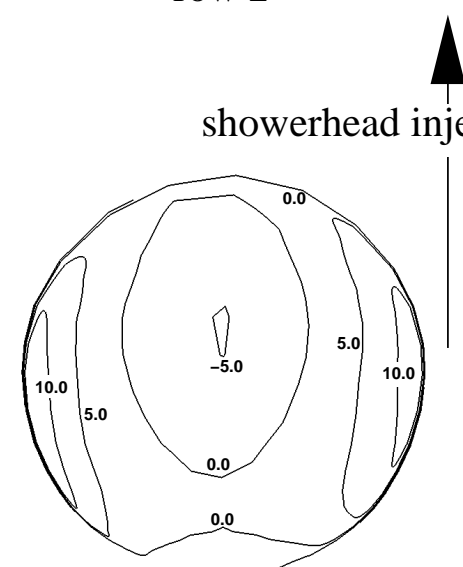

row 6

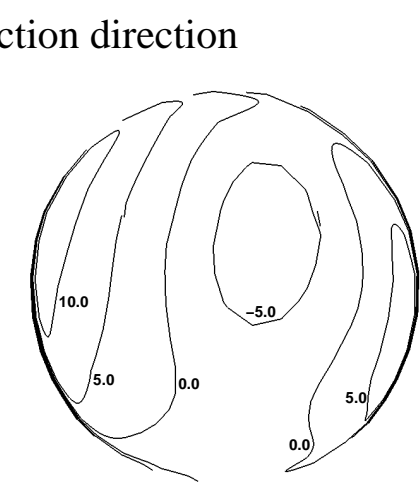

row 7

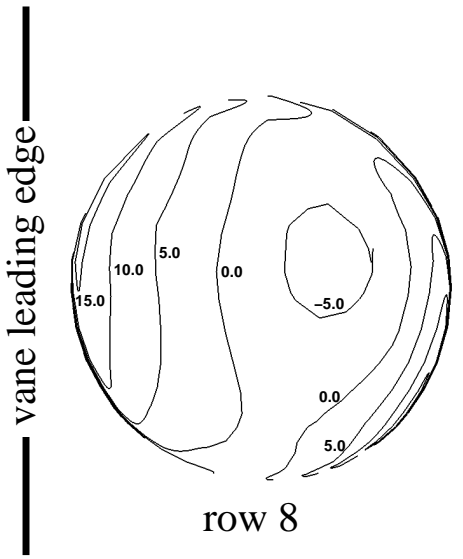

Note: All exit planes viewed along hole centerlines (not to scale)

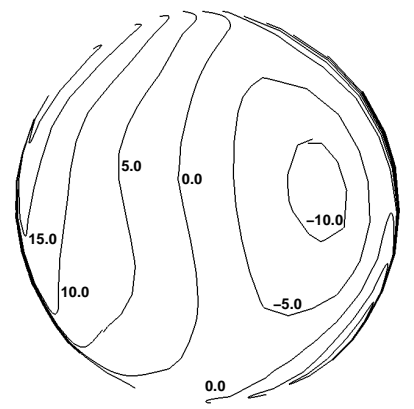

row 9

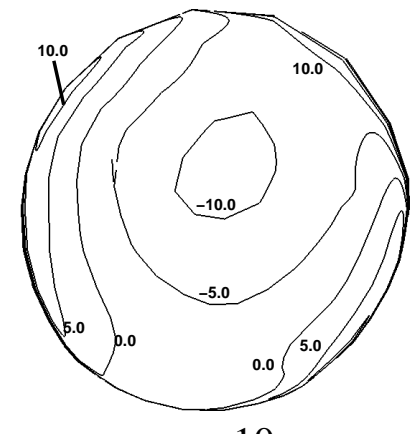

row 10

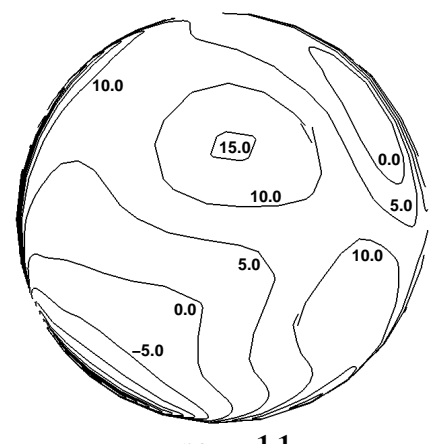

row 11

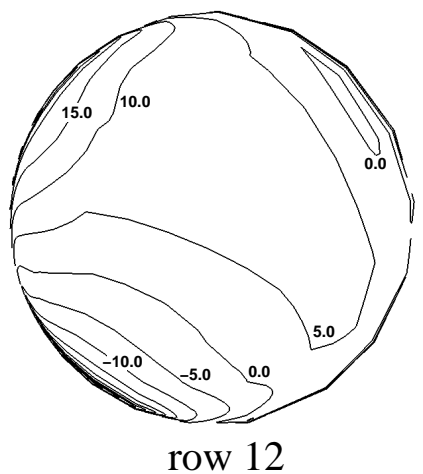

streamwise direction

$\Delta \beta$ (degrees)

Figure 12: Film hole exit spanwise angle profiles 


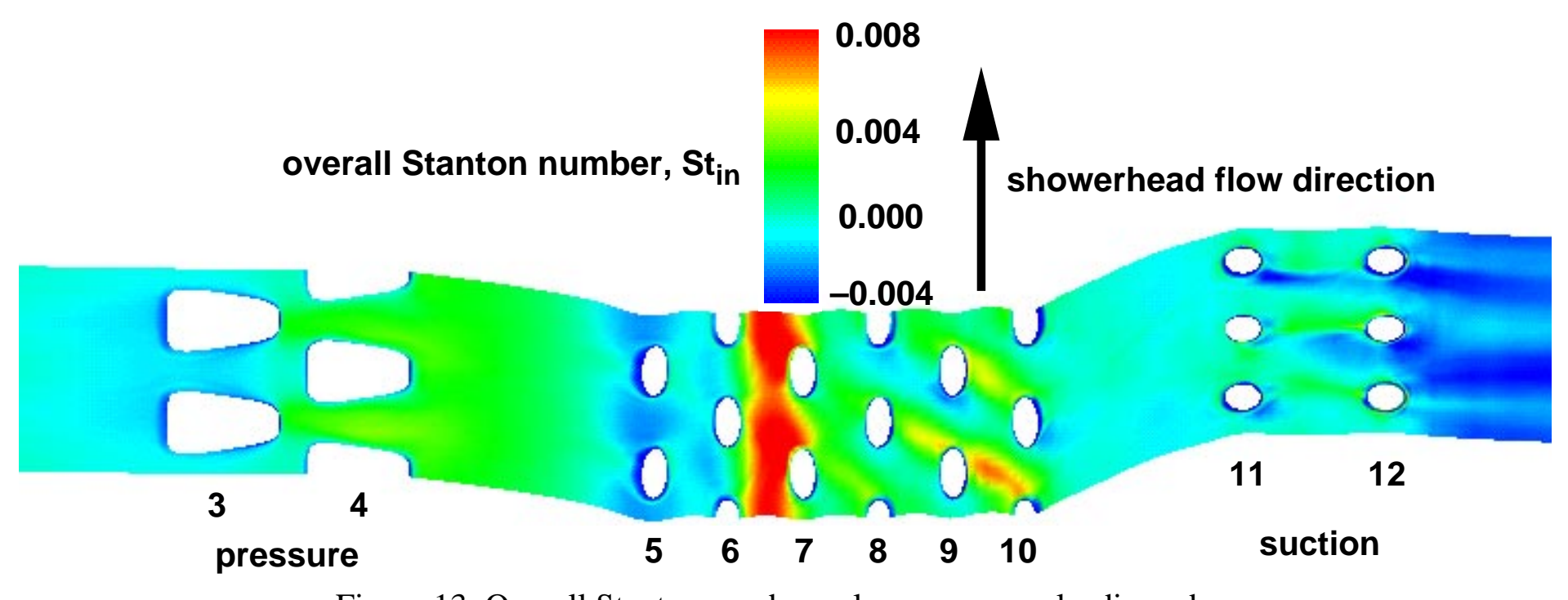

Figure 13: Overall Stanton number values near vane leading edge

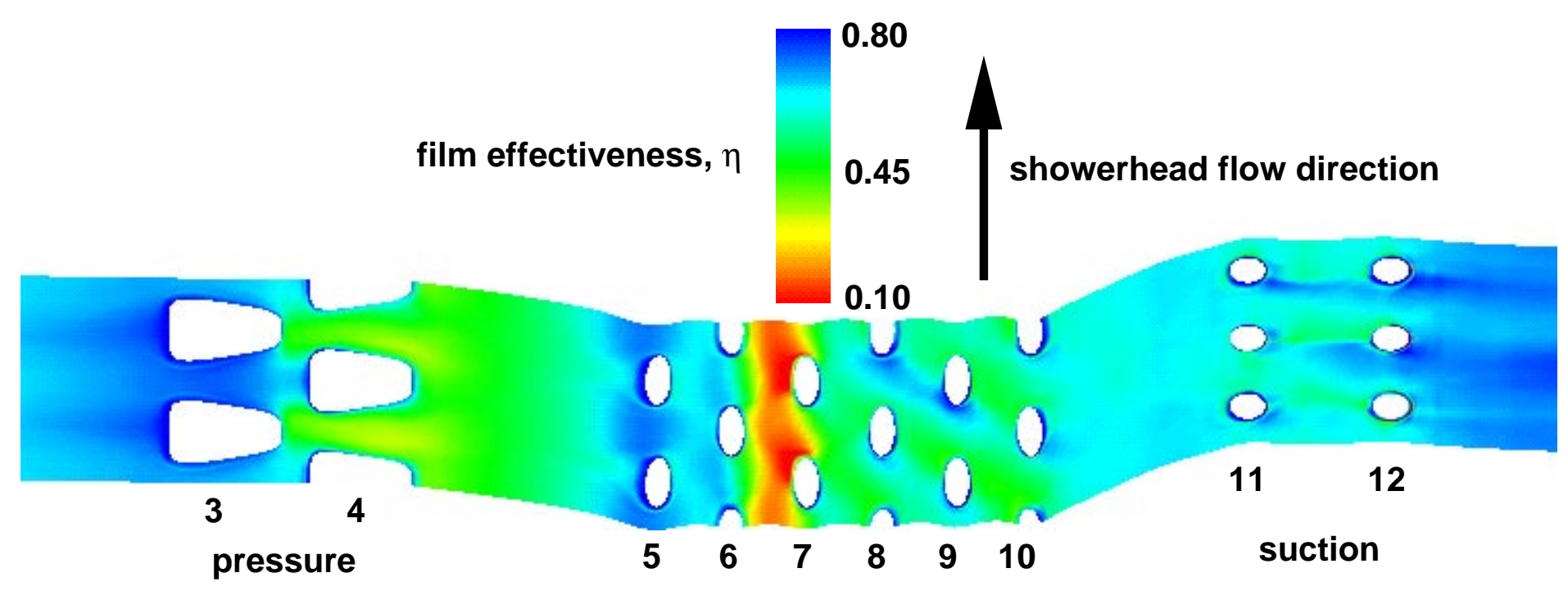

Figure 14: Film effectiveness values near vane leading edge

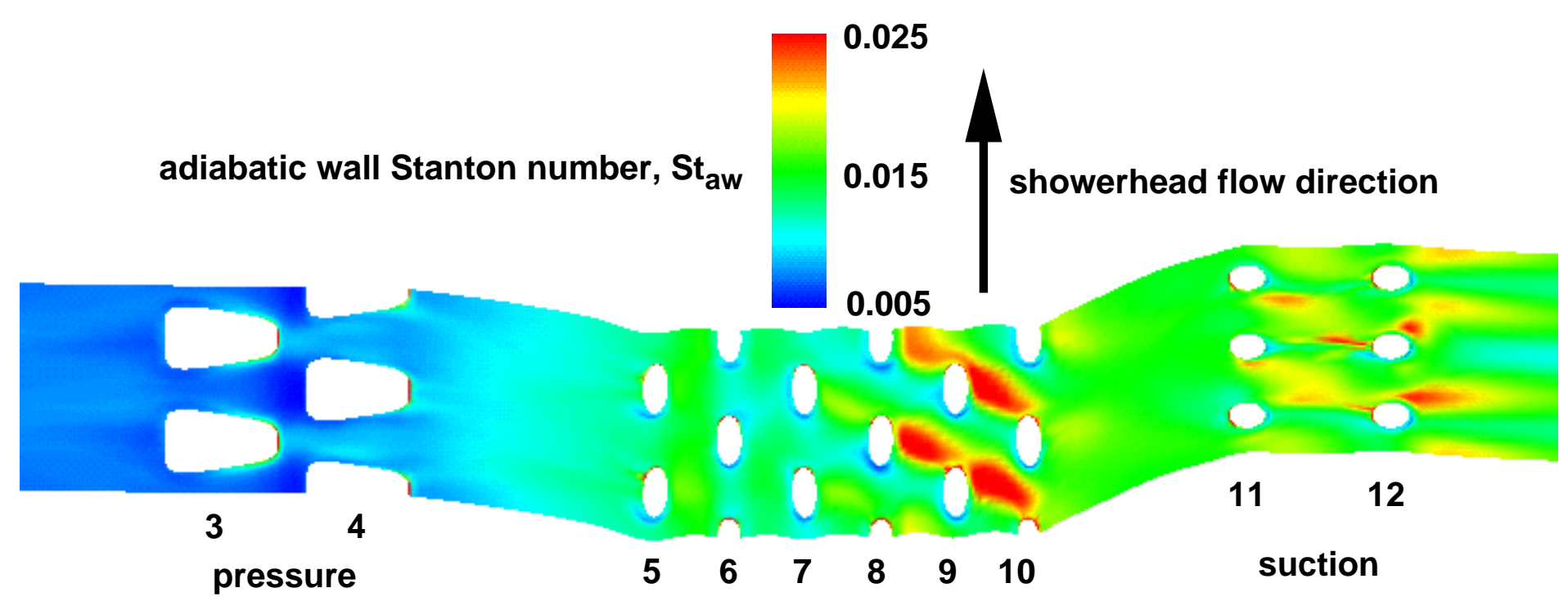

Figure 15: Adiabatic wall Stanton number values near vane leading edge 


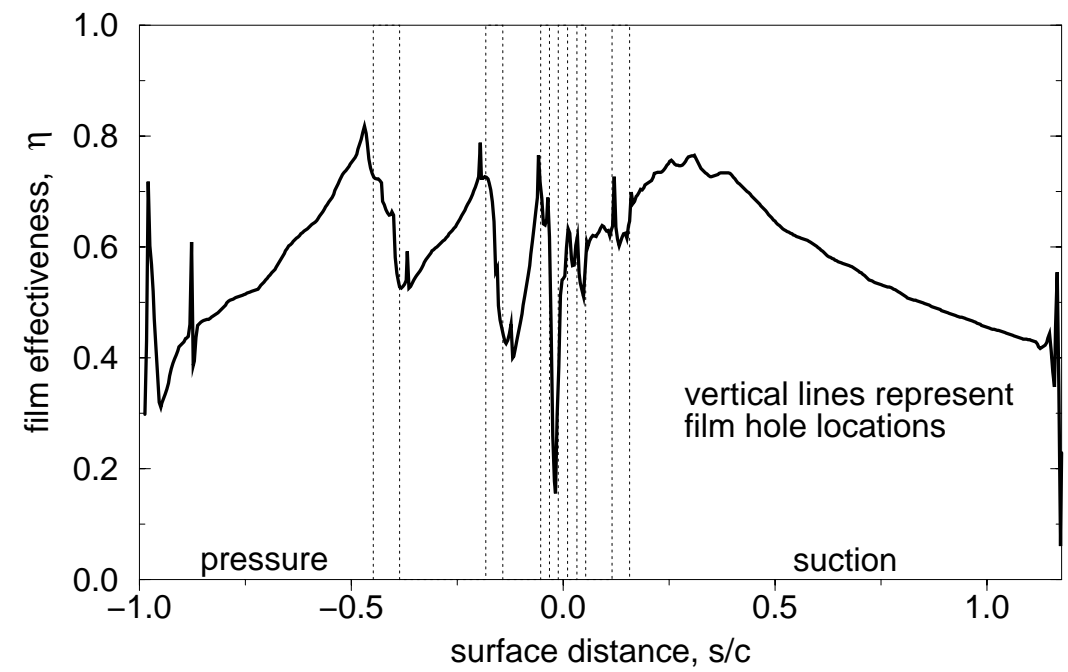

Figure 16: Span-average film effectiveness

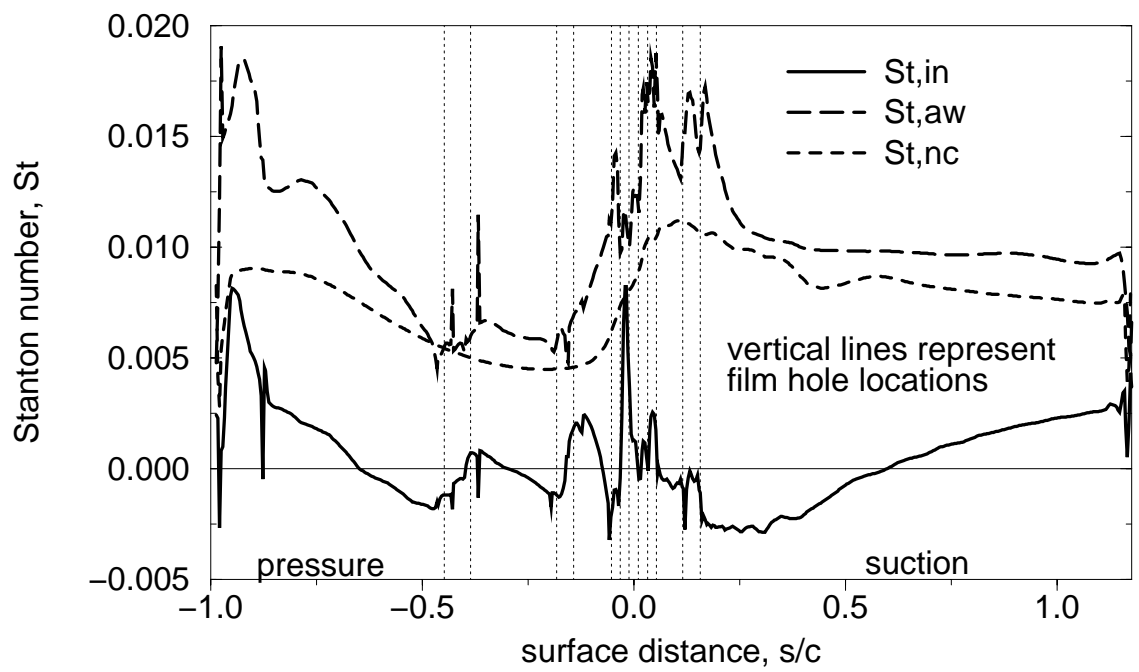

Figure 17: Span-average Stanton numbers

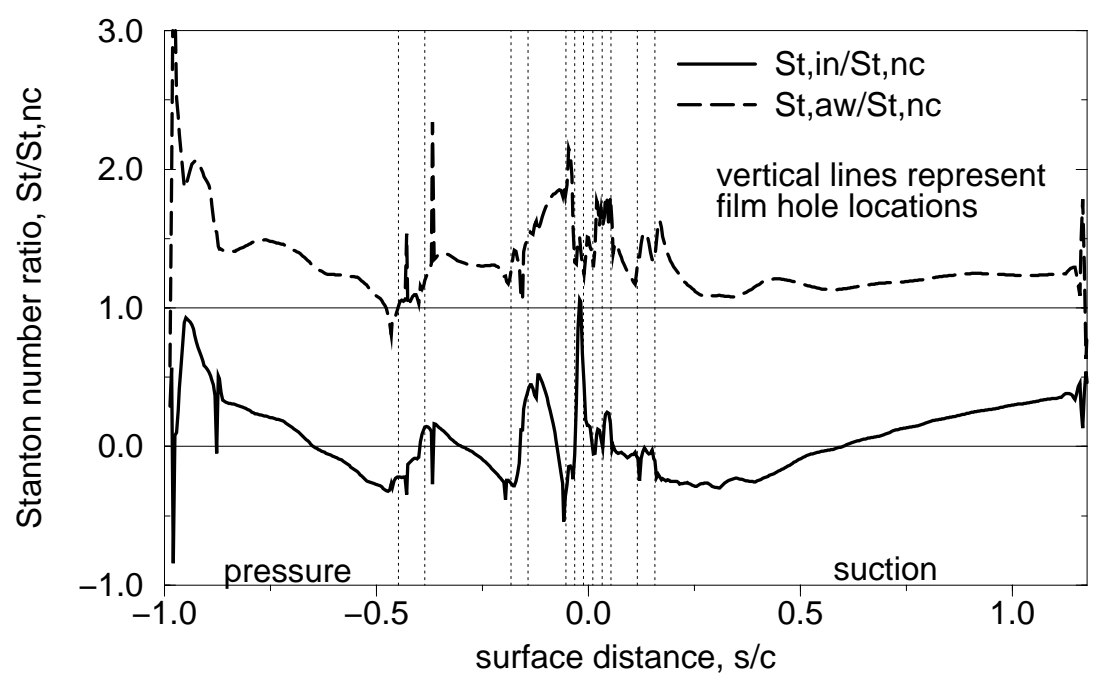

Figure 18: Span-average Stanton number ratios 
Public reporting burden for this collection of information is estimated to average 1 hour per response, including the time for reviewing instructions, searching existing data sources, gathering and maintaining the data needed, and completing and reviewing the collection of information. Send comments regarding this burden estimate or any other aspect of this collection of information, including suggestions for reducing this burden, to Washington Headquarters Services, Directorate for Information Operations and Reports, 1215 Jefferson Davis Highway, Suite 1204, Arlington, VA 22202-4302, and to the Office of Management and Budget, Paperwork Reduction Project (0704-0188), Washington, DC 20503.

\begin{tabular}{|l|l|r|}
\hline 1. AGENCY USE ONLY (Leave blank) & $\begin{array}{c}\text { 2. REPORT DATE } \\
\text { April } 1999\end{array}$ & $\begin{array}{r}\text { 3. REPORT TYPE AND DATES COVERED } \\
\text { Technical Memorandur }\end{array}$
\end{tabular}

\section{TITLE AND SUBTITLE}

5. FUNDING NUMBERS

A Three-Dimensional Coupled Internal/External Simulation of a Film-Cooled

Turbine Vane

6. AUTHOR(S)

James D. Heidmann, David L. Rigby, and Ali A. Ameri

WU-523-26-13-00

\section{PERFORMING ORGANIZATION NAME(S) AND ADDRESS(ES)}

National Aeronautics and Space Administration

John H. Glenn Research Center at Lewis Field

Cleveland, Ohio 44135-3191

8. PERFORMING ORGANIZATION REPORT NUMBER

E-11638

\section{SPONSORING/MONITORING AGENCY NAME(S) AND ADDRESS(ES)}

10. SPONSORING/MONITORING AGENCY REPORT NUMBER

National Aeronautics and Space Administration

Washington, DC 20546-0001

NASA TM-1999-209078

\section{SUPPLEMENTARY NOTES}

Prepared for the 44th Gas Turbine and Aeroengine Congress, Exposition, and Users' Symposium sponsored by the International Gas Turbine Institute of the American Society of Mechanical Engineers, Indianapolis, Indiana, June 7-10, 1999. James D. Heidmann, NASA Glenn Research Center; David L. Rigby, Dynacs Engineering Co., Inc., 2001 Aerospace Parkway, Brook Park, Ohio 44142 (work funded by NASA Contract NAS3-98008); and Ali A. Ameri, AYT Corporation, 2001 Aerospace Parkway, Brook Park, Ohio 44142 (work funded by NASA Contract NAS3-27571). Responsible person, James D. Heidmann, organization code 5820, (216) 433-3604.

\begin{tabular}{|l|l}
\hline 12a. DISTRIBUTION/AVAILABILITY STATEMENT & 12b. DISTRIBUTION CODE
\end{tabular}

Unclassified - Unlimited

Subject Categories: 34, 07, and 02

Distribution: Nonstandard

This publication is available from the NASA Center for AeroSpace Information, (301) 621-0390.

\section{ABSTRACT (Maximum 200 words)}

A three-dimensional Navier-Stoker simulation has been performed for a realistic film-cooled turbine vane using the LeRCHT code. The simulation includes the flow regions inside the coolant plena and film cooling holes in addition to the external flow. The vane is the subject of an upcoming NASA Glenn Research Center experiment and has both circular cross-section and shaped film cooling holes. This complex geometry is modeled using a multi-block grid which accurately discretizes the actual vane geometry including shaped holes. The simulation matches operating conditions for the planned experiment and assumes periodicity in the spanwise direction on the scale of one pitch of the film cooling hole pattern. Two computations were performed for different isothermal wall temperatures, allowing independent determination of heat transfer coefficients and film effectiveness values. The results indicate separate localized regions of high heat transfer coefficient values, while the shaped holes provide a reduction in heat flux through both parameters. Hole exit data indicate rather simple skewed profiles for the round holes, but complex profiles for the shaped holes with mass fluxes skewed strongly toward their leading edges.

\section{SUBJECT TERMS}

Turbines; Heat transfer; Film cooling 15. NUMBER OF PAGES

\begin{tabular}{|c|c|c|}
\hline $\begin{array}{c}\text { 17. SECURITY CLASSIFICATION } \\
\text { OF REPORT } \\
\text { Unclassified }\end{array}$ & $\begin{array}{c}\text { 18. SECURITY CLASSIFICATION } \\
\text { OF THIS PAGE } \\
\text { Unclassified }\end{array}$ & $\begin{array}{c}\text { 19. SECURITY CLASSIFICATION } \\
\text { OF ABSTRACT } \\
\text { Unclassified }\end{array}$ \\
\hline
\end{tabular}

